\title{
Ecological Factors and Diversification among Neotropical Characiforms
}

\section{Cástor Guisande, ${ }^{1}$ Patricia Pelayo-Villamil, ${ }^{2}$ Manuel Vera, ${ }^{3}$ Ana Manjarrés-Hernández, ${ }^{4}$ Mónica R. Carvalho, ${ }^{5}$ Richard P. Vari, ${ }^{6}$ Luz Fernanda Jiménez, ${ }^{2}$ Carlos Fernández, ${ }^{3}$ Paulino Martínez, ${ }^{3}$ Edgar Prieto-Piraquive, ${ }^{7}$ Carlos Granado-Lorencio, ${ }^{7}$ and Santiago R. Duque ${ }^{4}$}

\author{
${ }^{1}$ Facultad de Ciencias, Universidad de Vigo, Lagoas-Marcosende, 36200 Vigo, Spain \\ ${ }^{2}$ Grupo de Ictiología, Universidad de Antioquia, A.A. 1226, Medellín, Colombia \\ ${ }^{3}$ Departamento de Xenética, Facultade de Veterinaria, Universidade de Santiago de Compostela, Campus de Lugo, \\ Avenida Carballo Calero s/n 27002 Lugo, Spain \\ ${ }^{4}$ Instituto Amazónico de Investigaciones (IMANI), Universidad Nacional de Colombia, Km 2 vía Tarapacá, Leticia, Colombia \\ ${ }^{5}$ Instituto de Biología, Universidad de Antioquia, A.A. 1226, Medellín, Colombia \\ ${ }^{6}$ National Museum of Natural History, Smithsonian Institution, P.O. Box 37012, MRC 159, Washington, DC, USA \\ ${ }^{7}$ Departamento de Biología Vegetal y Ecología, Facultad de Biología, Universidad de Sevilla, \\ Avenida de Reina Mercedes s/n, 41012-Sevilla, Spain \\ Correspondence should be addressed to Cástor Guisande, castor@uvigo.es
}

Received 25 August 2011; Revised 4 December 2011; Accepted 31 January 2012

Academic Editor: J. J. Wiens

Copyright ( 2012 Cástor Guisande et al. This is an open access article distributed under the Creative Commons Attribution License, which permits unrestricted use, distribution, and reproduction in any medium, provided the original work is properly cited.

\begin{abstract}
Morphological and DNA sequence data has been used to propose hypotheses of relationships within the Characiformes with minimal comparative discussion of causes underpinning the major intraordinal diversification patterns. We explore potential primary morphological factors controlling the early diversification process in some Neotropical characiforms as the first step to identifying factors contributing to the pronounced intraordinal morphological and species diversity. A phylogenetic reconstruction based on 16S rDNA (mitochondrial) and 18S rDNA (nuclear) genes provided the framework for the identification of the main morphological differences among the Acestrorhynchidae, Anostomidae, Characidae, Ctenoluciidae, Curimatidae, Cynodontidae, Gasteropelecidae, Prochilodontidae and Serrasalmidae. Results indicate an initial split into two major groupings: (i) species with long dorsal-fin bases relative to the size of other fins (Curimatidae, Prochilodontidae, Anostomidae, Serrasalmidae) which primarily inhabit lakes, swamps, and rivers (lineage I); and (ii) species with short dorsal-fin bases (Acestrorhynchidae, Gasteropelecidae, Characidae) which primarily inhabit creeks and streams (lineage II). The second diversification stage in lineage I involved substantial morphological diversification associated with trophic niche differences among the monophyletic families which range from detritivores to large item predators. Nonmonophyly of the Characidae complicated within lineage II analyzes but yielded groupings based on differences in pectoral and anal fin sizes correlated with life style differences.
\end{abstract}

\section{Introduction}

The speciose nature of tropical freshwater fish faunas has attracted the attention of many scientists $[1,2]$. Prominent among the studied taxa are East African cichlids, with these studies yielding a general agreement that both sexual selection and morphological adaptation, particularly of the feeding apparatus, were the factors responsible for the explosive radiation of cichlids [3]. The relative timing and importance of these mechanisms remain unclear; however, it has been proposed that trophic differentiation played an important role during the early stages of the speciation process in cichlids. An alternative hypothesis proposes that ecological divergence and adaptive morphological change are not the primary cause of speciation in cichlids, but rather occur following the establishment of genetic isolation via other 
mechanisms (see [3]). Another excellent group on which to examine the factors responsible of the diversification process is the Characiformes, a speciose order widespread in tropical freshwaters of Africa and the Neotropics.

The Characiformes includes over 1996 species (although 24 species were described in 2011, so it seems that the cumulative species description curves for Characiformes have not yet closely approached its asymptote), now divided among 20 families, of which four are mostly African (Alestidae, Citharinidae, Distichodontidae, and Hepsetidae), and the others mostly Neotropical (Acestrorhynchidae, Anostomidae, Chalceidae, Characidae, Chilodontidae, Crenuchidae, Ctenoluciidae, Curimatidae, Cynodontidae, Erythrinidae, Gasteropelecidae, Hemiodontidae, Lebiasinidae, Parodontidae, Prochilodontidae, and Serrasalmidae) (see IPez [4]). Species diversity ranges dramatically among Neotropical families from a high of nearly 1200 species in the Characidae to only seven species in the Ctenoluciidae. More noteworthy is the dramatic diversity in body shape across the Characiformes, which is arguably the most pronounced within epicontinental fish faunas [5]. This range in external morphology is matched and in many instances surpassed by that in internal systems.

The phylogeny of various subunits of Neotropical characiforms has been studied based on information from diverse genetic sequences [6-10] and morphological characters [11-15]. The aim of most of these studies was to obtain a robust phylogeny and all were to varying degrees informative as to the core question of evolutionary relationships within the order. One informative way to address that question is to use phylogenetic trees as a framework to identify the morphological differences among the different clades. The phylogeny can also be used to address the phylogenetic signal of different ecological and morphological characters.

The aim of this study was to examine whether there were differences in habitat and trophic morphology among the clades obtained in a phylogenetic tree, among species that belong to a major subset of the families of Neotropical characiforms. Our aim was not to generate an all inclusive phylogeny within the order Characiformes, but to generate a phylogeny appropriate for addressing specific ecologi$\mathrm{cal} /$ evolutionary questions involving those species for which we have morphological data. Machine learning techniques were used to identify the main morphometric and trophic characters that discriminate lineages identified by phylogenetic hypotheses based on the analysis of mitochondrial (16S rRNA) and nuclear (18S rRNA) gene sequences. These hypotheses and the morphological features that differ to greater degrees among clades were assessed for phylogenetic signal in order to test the degree to which closely related families resemble or diverge from each another and to examine character dependence across lineage histories.

\section{Material and Methods}

2.1. Fish Sampling. The taxonomic sampling strategy was a dense taxonomic survey covering most of the families of Neotropical characiforms including both those that have been proposed to be monophyletic and others whose monophyly is questionable. This approach is preferable over the alternative of dense taxonomic sampling within a welldefined monophyletic family since the aim of the study was to identify early stages of the diversification process prior to the development of characters that delimit obviously monophyletic groups which are recognized taxonomically at the family level.

Specimens that served as the basis of the analyses were collected in a range of aquatic habitats within the Río Magdalena-Cauca and Amazon basins from January 2007 to June 2008 using multiple methods. Fishes were anesthetized with tricaine (MS-222, $250 \mathrm{mg} \mathrm{L}^{-1}$ ) in a tank prior to preservation with 977 individuals of 68 species analyzed. Species and number of individuals of each species used for the morphometric and DNA analyses are detailed in Table 1.

2.2. Habitat Preferences. Species were grouped according to their habitat preferences into those species that preferentially inhabit rivers, lakes/swamps, or creeks/streams.

\subsection{Morphometric and Trophic Measurements. A total of 32} morphological variables were measured in five to 29 adults of each sampled species without making any distinction between sexes since sexual dimorphism does not occur in these variables among characiforms (Figure 1). These variables were standardized relative to standard length (each measurement was divided by the standard length) and reflect the primary aspects of external morphology. Several trophic variables were measured on these individuals. These were the length of the digestive tract, the length of the first gill-arch (Figure 2), the number of gill rakers on the first arch, and the width and height of six gill rakers along both the central and upper segments of the first arch (Figure 2). Counts of the numbers of teeth on the maxilla, suspensorium, and dorsal and ventral portions of the gill arch were taken. The height and width of the first 5 teeth in both the upper and lower jaws were measured (see schematics in Figure 3 for modes of measurement of the different tooth types).

\subsection{DNA Extraction, PCR Amplification, and Sequencing.} Fifty-three species were incorporated into the molecular analysis. Genomic DNA was isolated from skeletal muscle using the Phenol-Chloroform DNA extraction protocol [16] or using DNeasy Blood and Tissue Kit (Qiagen, Hilden, Germany). At least two individuals per species were analyzed (Table 1). Double-stranded DNA was amplified for two ribosomal genes, one mitochondrial (16S rDNA) and the other nuclear (18S rDNA). Despite the high performance of mitochondrial DNA (mtDNA) for phylogenetic analysis, the use of both mtDNA and nuclear DNA (nDNA) markers has been emphasized, as the mitochondrial genome only represents a maternal perspective of the total historical record of sexually reproducing organisms [17-19]. Amplification of the mitochondrial $16 \mathrm{~S}$ rDNA region was carried out using 16Sa-L2510 and 16Sb-H3080 universal primers [20]. To amplify nuclear $18 \mathrm{~S} \mathrm{rDNA}$, a pair of primers was designed using available $18 \mathrm{~S}$ rDNA sequences in GenBank from brown 
TABLE 1: Number of individuals of each species analyzed for morphometric measurements and DNA sequences.

\begin{tabular}{|c|c|c|c|}
\hline Family & Species & $\begin{array}{l}\text { Morphometric } \\
\text { measurements }\end{array}$ & DNA \\
\hline \multirow{4}{*}{ Acestrorhynchidae } & Acestrorhynchus abbreviatus & 23 & 2 \\
\hline & Acestrorhynchus falcirostris & 7 & \\
\hline & Acestrorhynchus lacustris & 15 & \\
\hline & Acestrorhynchus microlepis & 11 & 2 \\
\hline \multirow{8}{*}{ Anostomidae } & Leporinus agassizii & 6 & \\
\hline & Leporinus fasciatus & 14 & \\
\hline & Leporinus muyscorum & 21 & 2 \\
\hline & Leporinus friderici & 14 & \\
\hline & Leporinus wolfei & 7 & \\
\hline & Rhytiodus argenteofuscus & 12 & \\
\hline & Rhytiodus microlepis & 16 & 2 \\
\hline & Schizodon fasciatus & 12 & 4 \\
\hline Chalceidae & Chalceus erythrurus & 17 & 4 \\
\hline \multirow{28}{*}{ Characidae } & Astyanax abramis & 18 & 2 \\
\hline & Astyanax fasciatus & 20 & 2 \\
\hline & Astyanax magdalenae & 10 & 2 \\
\hline & Astyanax microlepis & 14 & 2 \\
\hline & Brycon amazonicus & 13 & 2 \\
\hline & Brycon cephalus & 14 & 2 \\
\hline & Brycon henni & 20 & 2 \\
\hline & Brycon melanopterus & 12 & \\
\hline & Bryconops inpai & 14 & \\
\hline & Bryconops melanurus & 9 & 2 \\
\hline & Charax michaeli & 19 & 3 \\
\hline & Charax tectifer & 12 & 2 \\
\hline & Ctenobrycon hauxwellianus & 16 & 2 \\
\hline & Cynopotamus magdalenae & 13 & 2 \\
\hline & Hemibrycon boquiae & 14 & 2 \\
\hline & Hemibrycon dentatus & 14 & 2 \\
\hline & Moenkhausia comma & 15 & 2 \\
\hline & Moenkhausia lepidura & 16 & 2 \\
\hline & Moenkhausia melogramma & 16 & 2 \\
\hline & Roeboides dayi & 21 & \\
\hline & Roeboides myersii & 12 & 2 \\
\hline & Roeboides occidentalis & 7 & \\
\hline & Stethaprion erythrops & 14 & 2 \\
\hline & Tetragonopterus argenteus & 11 & 3 \\
\hline & Triportheus albus & 12 & 2 \\
\hline & Triportheus angulatus & 15 & 4 \\
\hline & Triportheus elongatus & 5 & \\
\hline & Triportheus magdalenae & 28 & 2 \\
\hline \multirow{2}{*}{ Ctenoluciidae } & Boulengerella maculata & 11 & 4 \\
\hline & Ctenolucius hujeta & 12 & 2 \\
\hline
\end{tabular}


Table 1: Continued.

\begin{tabular}{|c|c|c|c|}
\hline Family & Species & $\begin{array}{l}\text { Morphometric } \\
\text { measurements }\end{array}$ & DNA \\
\hline \multirow{10}{*}{ Curimatidae } & Curimatopsis macrolepis & 24 & 2 \\
\hline & Cyphocharax magdalenae & 24 & 2 \\
\hline & Cyphocharax spiluropsis & 10 & \\
\hline & Potamorhina altamazonica & 17 & 4 \\
\hline & Potamorhina latior & 14 & 2 \\
\hline & Psectrogaster amazonica & 12 & 2 \\
\hline & Psectrogaster rhomboides & 16 & 2 \\
\hline & Psectrogaster rutiloides & 14 & 2 \\
\hline & Steindachnerina guentheri & 17 & 2 \\
\hline & Steindachnerina hypostoma & 11 & 2 \\
\hline \multirow{2}{*}{ Cynodontidae } & Hydrolycus scomberoides & 8 & 2 \\
\hline & Rhaphiodon vulpinus & 11 & 4 \\
\hline \multirow{4}{*}{ Gasteropelecidae } & Carnegiella schereri & 10 & \\
\hline & Carnegiella strigata & 15 & 2 \\
\hline & Thoracocharax securis & 9 & \\
\hline & Thoracocharax stellatus & 16 & 2 \\
\hline \multirow{3}{*}{ Prochilodontidae } & Prochilodus magdalenae & 29 & 2 \\
\hline & Prochilodus nigricans & 15 & 2 \\
\hline & Semaprochilodus insignis & 17 & 2 \\
\hline \multirow{6}{*}{ Serrasalmidae } & Colossoma macropomum & 10 & 2 \\
\hline & Mylossoma aureum & 10 & 4 \\
\hline & Mylossoma duriventre & 18 & 2 \\
\hline & Pygocentrus nattereri & 17 & 2 \\
\hline & Serrasalmus elongatus & 11 & 2 \\
\hline & Serrasalmus rhombeus & 10 & 2 \\
\hline
\end{tabular}

trout (Salmo trutta, GenBank accession number: X98839), turbot (Scophthalmus maximus EF126038) and several siluriform species (Channallabes longicaudatus AJ876391, Ictalurus punctatus AF021880, Clarias jaensis AJ876386) and one characiform species (Prochilodus marggravii AY449633). The following primers were finally designed using the program Primer3 [21] 18S-448F 5' -AAACGGCTACCACATCCAAG$3^{\prime}$ and 18S-1041R 5' -CCTCCGACTTTCGTTCTTGA-3'.

PCR was performed in $50 \mu \mathrm{L}$ of reaction mixture containing 100-300 ng of template DNA, 1X PCR Gold Buffer, $2.5 \mathrm{mM} \mathrm{MgCl}_{2}, 0.4 \mathrm{mM}$ of each dNTP, 10 pmol of each primer, and 2.5 units of Ampli Taq Gold DNA polymerase (Applied Biosystems, Foster City, CA, USA). PCRs were carried out in a PTC-100 thermocycler (MJ Research) as follows: an initial denaturation step at $94^{\circ} \mathrm{C}$ for $10 \mathrm{~min} ; 35$ cycles of $93^{\circ} \mathrm{C}$ for $1 \mathrm{~min}$, annealing $\left(50^{\circ} \mathrm{C}\right.$ for $16 \mathrm{~S} \mathrm{rDNA}$ and $58^{\circ} \mathrm{C}$ for $18 \mathrm{~S} \mathrm{rDNA}$ ) for $1 \mathrm{~min}$ and $72^{\circ} \mathrm{C}$ for $3 \mathrm{~min}$; a final extension step at $72^{\circ} \mathrm{C}$ of extension for $10 \mathrm{~min}$. PCR products were purified using the Spinclean PCR Purification Kit (MyBiotech, Seoul, South Korea) and sequenced following the ABI Prism BigDye Terminator v3.1 Cycle Sequencing Kit protocol on an ABI 3730 DNA sequencer (Applied Biosystems, Foster City, CA, USA).
2.5. Phylogenetic Analyses. Sequences for both markers (16S rDNA and 18S rDNA) were compared with homologous sequences available on public databases. Errors and nucleotide indeterminations were checked using the program SeqScape 2.5 (Applied Biosystems). This program checks the quality of each nucleotide site (a quality value QV is given for each site) showing the electropherogram for each sequence and allowing its editing. The sequences derived herein were compared with homologous ones available in public databases. Variable sites were checked by hand using the program SeQScApe 2.5 (Applied Biosystems, Foster City, CA, USA). Sequences were aligned using Clustal X 2.0 [22] with default parameters for gap opening $(=15)$ and gap extension costs $(=6.66)$. The different haplotypes from the Clustal alignments were detected using the Mega 4.0 program [23]. All of the different haplotypes for each species were included in the analyses. The MegA 4.0 program was also used to estimate the number of nucleotide changes and genetic distances between the characiform taxa in the analyses (families and species). All haplotype sequences have been submitted to GenBank (16S rDNA accession numbers: FJ944707 to FJ944763; 18S rDNA accession numbers: FJ944764 to FJ944818, see Table 2). The program 


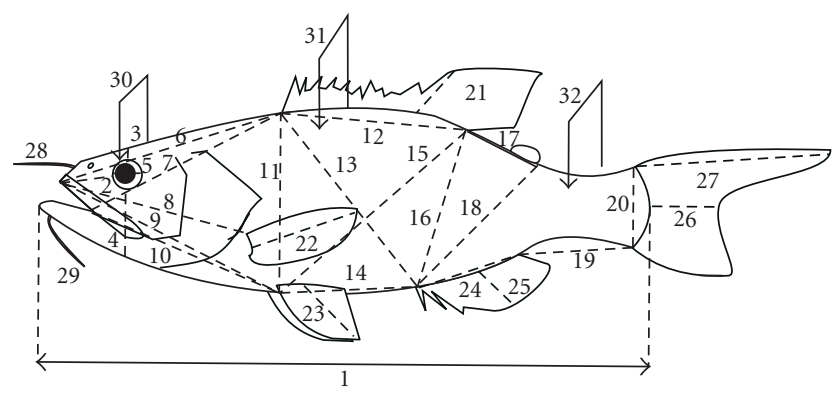

FIGURE 1: Diagram showing morphometric characters measured in examined fishes. M1 standard length; M2 distance from tip of snout to anterior margin of the eye; M3 perpendicular distance from upper edge of orbit to dorsal profile; M4 perpendicular distance from lower margin of orbit to ventral profile; M5 maximum diameter of orbit; M6 distance from tip of snout to origin of dorsal fin; M7 distance from tip of snout to origin of dorsal fin; M8 distance from tip of snout to dorsal point of insertion of pectoral fin; M9 distance from tip of snout to dorsal point of insertion of pelvic fin; M10 distance from tip of snout to dorsal point of insertion of pelvic fin; M11 distance from origin of dorsal fin to dorsal point of insertion of pelvic fin; M12 length of base of dorsal fin; M13 distance from origin of dorsal fin to origin of anal fin; M14 distance from origin of pelvic fin to origin of anal fin; M15 distance from terminus of base of dorsal fin to origin of pelvic fin; M16 distance from terminus of base of dorsal fin to origin of anal fin; M17 distance from terminus of base of dorsal fin to origin of adipose fin; M18 distance from terminus of base of adipose fin to origin of anal fin; M19 distance from terminus of base of anal fin, including to base of caudal fin; M20 width of caudal fin at its base; M21 length of longest dorsal fin ray; M22 length of longest pectoral fin ray; M23 length of longest pelvic fin ray; M24 length of base of anal fin; M25 length of longest anal fin ray; M26 distance from center of caudal peduncle to distal margin of caudal fin; M27 length of longest caudal fin ray; M30 interorbital width; M31 greatest width if central part of body; M32 width of middle of caudal peduncle.

Modeltest 3.7 [24] was used to determine the optimal model of nucleotide evolution for each data set based on the Akaike Information Criterion (AIC; [25]) (General time Reversible model with a gamma parameter of 0.6024 and a proportion of invariable sites of $0.4641(\mathrm{GTR}+\mathrm{I}+\mathrm{G})$ for 16S rDNA; the Tamura Nei equal base frequencies (TrNef) model was used with a gamma parameter of 0.6487 and a proportion of invariable sites of 0.2210 ( TrNef $+\mathrm{I}+\mathrm{G}$ ) for $18 \mathrm{~S}$ rDNA).

In order to evaluate the difference between both markers, incongruence length differences (ILDs) were calculated using the partition homogeneity test [26]. Heuristic searches with 1000 replicates of one simple taxon addition and tree bisection reconnection (TBR) branch swapping were undertaken using PAUP* 4.0b [27]. The question of whether it is preferable "to combine or not to combine" data sets for phylogenetic analysis remains controversial. Therefore, we analyzed both data sets separately and in combination to potentially increase the descriptive efficiency and explanatory power of data $[28,29]$. Heterogeneity tests were not used to automatically justify the separation of character partitions, but were used to assess the distribution, nature, and extent of conflict among data sets $[29,30]$. Cunningham [31] applied three different incongruence tests to predict when mtDNA and nDNA data could be combined. Following this author, only in instances when $P \leq 0.01$ was a combined data matrix considered to be less accurate than individual data partitions. Moreover, Wiens [32] suggested that two data sets may differ in only part of their histories. ILD methods only show a global significance value for the comparison among trees.

Phylogenetic analyses were carried out using Bayesian Inference (BI) and Maximum Parsimony (MP) methods on three datasets: $16 \mathrm{~S}$ rDNA data, $18 \mathrm{~S}$ rDNA data, and combined data. Bayesian analysis is a model-based method able to account for the heterogeneous substitution processes of the two different genes analyzed, thereby complementing the pure most parsimonious reconstructions of the MP methods. BI analyses were implemented using MrBayes 3.1.2 [33, 34]. When data were combined using the partition option of MrBAYEs, the specific mitochondrial and nuclear nucleotide substitution rates obtained with Modeltest were applied. Two independent Metropolis-Coupled Markov Chain Monte Carlo processes were run for 1 cold and 3 hot chains and $1,000,000$ generations with trees being sampled every 100 generations for a total of 10,000 trees. Independent runs were combined with the 250,000 initial generations $(2,500$ trees) used as a burn-in period (stationarity was assumed when standard deviation of split frequencies was lower than 0.01 ) and discarded from the analyses. MP analyses were implemented in PAUP* 4.0b [27], using a heuristic search with a simple addition sequence and TBR branch swapping. The heuristic search was limited to a maximum of 10,000 saved trees. All characters were unordered, all character transformations were equally weighted, and branches with maximum lengths of zero were collapsed. To avoid any presumption concerning the nature and location of insertion/deletion events and subjective constraints on character state change, gaps were treated as missing data rather than as a fifth character state. The reliability of nodes was assessed using 1,000 nonparametric bootstrap replicates [35]. The $16 \mathrm{~S}$ rDNA and 18S rDNA sequences from two cypriniform species available on GenBank database (Cyprinus carpio DQ983941-AF133089 and Danio rerio AY788011-BX296557) were used as outgroups based on hypotheses of higherlevel relationships within the Ostariophysi $[6,36]$. The tree topologies obtained with the different methods were compared using the Shimodaira and Hasegawa test [37] implemented in Paup.

2.6. Statistical Method for Testing Which Morphological Variables Differ among Clades. Classification and regression trees (CARTs) were used to identify the main morphometric and trophic characters that discriminate the clades obtained in the phylogenetic analyses. We used MATLAB as platform to run CARTs. The species were split into groups based on the phylogenic tree so that for each node of the phylogenic tree we introduced into CARTs the mean morphometric and trophic measurements obtained from all species grouped according to the assemblages retrieved by the phylogenetic tree at each node. 


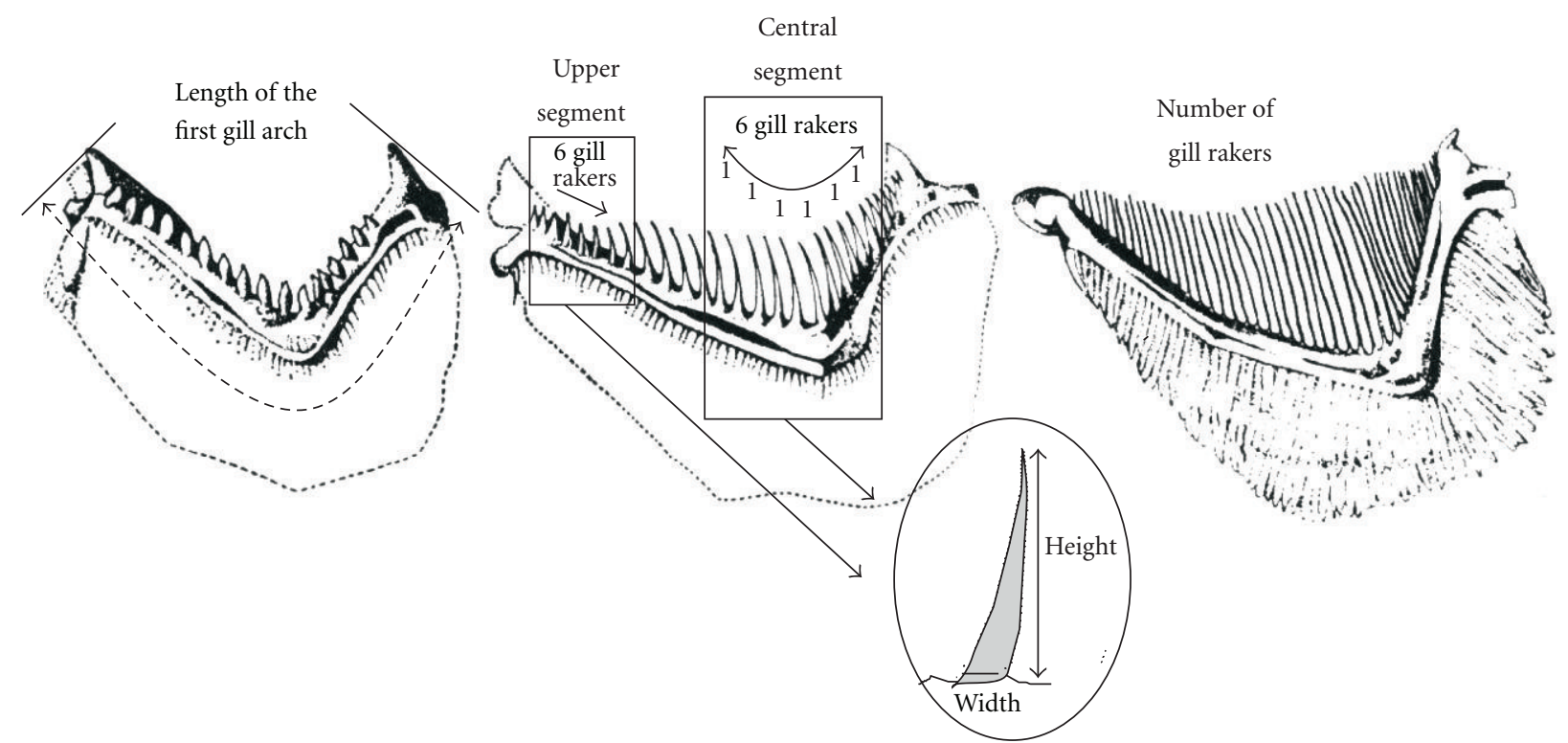

FIGURE 2: Diagram of variables measured on first gill arch for the analysis.
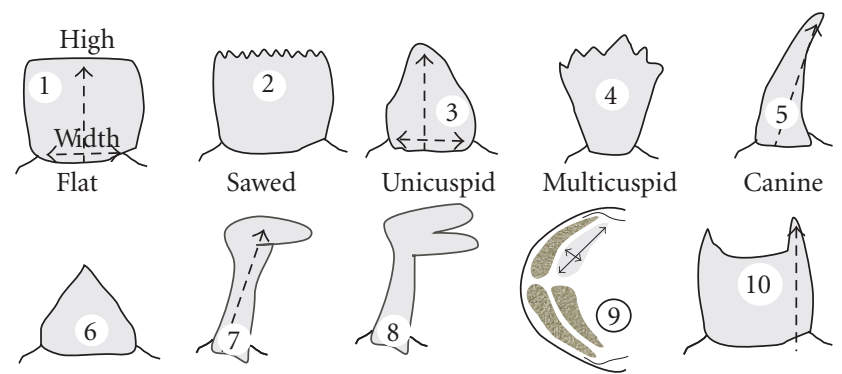
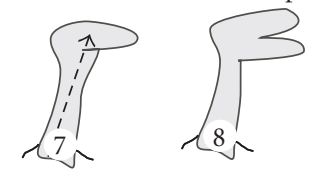

Conic

Spatula
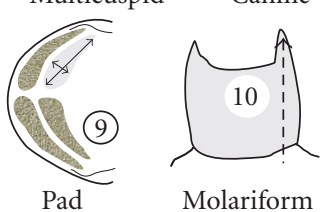

Molariform

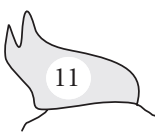

Crenulate

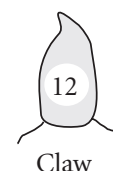

Claw

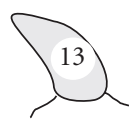

Viliform

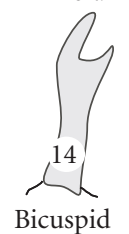

FiguRE 3: Diagram of different type of teeth coded in the analysis.

CARTs are nonparametric statistical techniques with great flexibility for adapting to any data-generating process. There are two primary reasons for selecting this methodology instead of traditional statistical methods or other pattern recognition techniques. CARTs do not assume linearity, an important consideration in fishes in which allometries are frequently observed. Second, CARTs have high interpretability and low computational burden relative to other techniques with comparable benefits. Although they are not new techniques [38], only recently has their importance been appreciated with the huge increase in the amount of data produced by the intensive use of new information technologies. In this sense, they are one of the most successful techniques in the field of data mining and machine learning [39].

In the classification trees, we assume the existence of several disjoint classes $C_{1}, \ldots, C_{c}$ of individuals with labels $Y(x)=k \in \mathcal{Y}=\{1, \ldots, c\}$ (although the labels can be

subject to noise). When the CART is trained from the data, the prediction of the class of a new point $x$ is based on a partition of the input space in exhaustive regions $h$ and disjoint ones $A_{1}, \ldots, A_{h}$ that, in terms of classes, are as homogenous as possible. If $x \in A_{k}$ for any $k$, the prediction made by CART for this new point $x$ is the majority class in the region $A_{k}$ to which $x$ belongs.

The regions $A_{j}, j=1, \ldots, h$ in which the CART divides the input space $\mathcal{X}$ are delimited by segments parallel to the axes, that is, there are Cartesian products of intervals:

$$
A_{j}=\prod_{i=1}^{d} I_{j i}
$$

where $I_{j i}=\left[a_{j i}, b_{j i}\right] \subset \mathbb{R}$ is the $j$ th interval at the axis of each $i$ th variable of the region $A_{j}$.

The training algorithm of the CARTs [37-41] successively divides the input space into a new group of disjoint and exhaustive regions, until it verifies one of the stopping criteria. In the first iteration, the space is divided into two disjoint regions. Each subsequent iteration divides each of the regions of the immediately preceding iteration into two new regions, except when one of the regions satisfies any stopping criterion.

2.7. Testing the Significance of CARTs. An ANOVA (Analysis of variance) or Kruskal-Wallis test was performed for each node of the phylogenetic tree with the mean morphometric and trophic characters obtained for the species of each group within the node [42]. For testing the significance of each node, all the raw data obtained for each species was used rather than solely the mean values.

2.8. Phylogenetic Signal and Character Optimization. The evaluation of character consistencies within lineages can reveal patterns or trends of character resemblance between 
TABLE 2: Examined families, genera and species along with GenBank accession numbers for sequences analyzed in this study.

\begin{tabular}{|c|c|c|c|}
\hline \multirow{2}{*}{ Family } & \multirow{2}{*}{ Species } & \multicolumn{2}{|c|}{ GenBank accession number } \\
\hline & & 16S rDNA & 18S rDNA \\
\hline \multirow{2}{*}{ Acestrorhynchidae } & Acestrorhynchus abbreviatus & FJ944707 & FJ944764 \\
\hline & Acestrorhynchus microlepis & FJ944708, FJ944709 & FJ944765, FJ944766 \\
\hline \multirow{4}{*}{ Anostomidae } & Leporinus fasciatus & FJ944710 & FJ944767 \\
\hline & Leporinus muyscorum & FJ944711 & FJ944768 \\
\hline & Rhytiodus microlepis & FJ944712 & FJ944769 \\
\hline & Schizodon fasciatus & FJ944713 & FJ944770 \\
\hline Chalceidae & Chalceus erythrurus & FJ944723 & FJ944779 \\
\hline \multirow{23}{*}{ Characidae } & Astyanax abramis & FJ944714 & FJ944771 \\
\hline & Astyanax aff. fasciatus & FJ944715 & FJ944772 \\
\hline & Astyanax magdalenae & FJ944716 & FJ944773 \\
\hline & Astyanax microlepis & FJ944717 & FJ944774 \\
\hline & Brycon amazonicus & FJ944718 & FJ944775 \\
\hline & Brycon cephalus & FJ944719 & FJ944776 \\
\hline & Brycon henni & FJ944720 & FJ944777 \\
\hline & Bryconops melanurus & FJ944721, FJ944722 & FJ944778 \\
\hline & Charax michaeli & FJ944724 & FJ944780 \\
\hline & Charax tectifer & FJ944725 & FJ944781 \\
\hline & Ctenobrycon hauxwellianus & FJ944726 & FJ944782 \\
\hline & Cynopotamus magdalenae & FJ944727 & FJ944783 \\
\hline & Hemibrycon boquiae & FJ944728 & FJ944784 \\
\hline & Hemibrycon dentatus & FJ944729 & FJ944785 \\
\hline & Moenkhausia comma & FJ944730 & FJ944786 \\
\hline & Moenkhausia lepidura & FJ944731 & FJ944787 \\
\hline & Moenkhausia melogramma & FJ944732 & FJ944788 \\
\hline & Roeboides myersii & FJ944733 & FJ944789 \\
\hline & Stethaprion erythrops & FJ944734 & FJ944790 \\
\hline & Tetragonopterus argenteus & FJ944735 & FJ944791 \\
\hline & Triportheus albus & FJ944736 & FJ944792 \\
\hline & Triportheus angulatus & FJ944737 & FJ944793 \\
\hline & Triportheus magdalenae & FJ944738 & FJ944794 \\
\hline \multirow{2}{*}{ Ctenoluciidae } & Boulengerella maculata & FJ944739 & FJ944795 \\
\hline & Ctenolucius hujeta & FJ944740 & FJ944796 \\
\hline \multirow{9}{*}{ Curimatidae } & Curimatopsis macrolepis & FJ944741 & FJ944797 \\
\hline & Cyphocharax magdalenae & FJ944742 & FJ944798 \\
\hline & Potamorhina altamazonica & FJ944743 & FJ944799 \\
\hline & Potamorhina latior & FJ944744 & FJ944800 \\
\hline & Psectrogaster amazonica & FJ944745 & FJ944801 \\
\hline & Psectrogaster rhomboides & FJ944746 & FJ944802 \\
\hline & Psectrogaster rutiloides & FJ944747 & FJ944803 \\
\hline & Steindachnerina guentheri & FJ944748 & FJ944804 \\
\hline & Steindachnerina hypostoma & FJ944749 & FJ944805 \\
\hline \multirow{2}{*}{ Cynodontidae } & Hydrolycus scomberoides & FJ944750 & FJ944806 \\
\hline & Rhaphiodon vulpinus & FJ944751 & FJ944807 \\
\hline
\end{tabular}


TABle 2: Continued.

\begin{tabular}{|c|c|c|c|}
\hline \multirow{2}{*}{ Family } & \multirow{2}{*}{ Species } & \multicolumn{2}{|c|}{ GenBank accession number } \\
\hline & & $16 \mathrm{~S}$ rDNA & $18 \mathrm{~S}$ rNA \\
\hline \multirow{2}{*}{ Gasteropelecidae } & Carnegiella strigata & FJ944752 & FJ944808 \\
\hline & Thoracocharax stellatus & FJ944753 & FJ944809 \\
\hline \multirow{3}{*}{ Prochilodontidae } & Prochilodus magdalenae & FJ944754 & FJ944810 \\
\hline & Prochilodus nigricans & FJ944755 & FJ944811 \\
\hline & Semaprochilodus insignis & FJ944756 & FJ944812 \\
\hline \multirow{6}{*}{ Serrasalmidae } & Colossoma macropomum & FJ944757 & FJ944813 \\
\hline & Mylossoma aureum & FJ944758 & FJ944814 \\
\hline & Mylossoma duriventre & FJ944759, FJ944760 & FJ944815 \\
\hline & Pygocentrus nattereri & FJ944761 & FJ944816 \\
\hline & Serrasalmus elongatus & FJ944762 & FJ944817 \\
\hline & Serrasalmus rhombeus & FJ944763 & FJ944818 \\
\hline
\end{tabular}

closely related species or groups, with these a function of their recent common evolutionary history.

The $K$-index developed by Blomberg et al. [43] is a descriptive statistic that compares the mean square error ratio, given the data and the phylogenetic tree, versus the expected mean square error, given the phylogenetic tree and a Brownian motion model assumed for the evolutionary process. This statistic anticipates a value of $K=1$ for characters fitting a Brownian motion model. Values of $K>1$ denote a phylogenetic signal, with trait variation being less than expected under a Brownian assumption, whereas values of $K<1$ denote a low phylogenetic signal and higher trait variation between closely related taxa. The $K$-index was estimated for all continuous characters using the picante package for $R$ ! [44, 45].

Phylogenetic signal estimation for discrete characters was based on a maximum likelihood approach. Pagel's Lambda $(\lambda)$ is a tree scaling parameter that detects whether or not the relationships specified by a topology produce patterns of character similarity analogous to those observed in the data [46]. This parameter multiplies all internal branches of the tree, conserving original branch lengths but not phylogenetic structure. Values of $\lambda=1$ and above denote phylogenetic signal. Lambda was optimized for all discrete characters and log-likelihood values for Pagel's $\lambda$ were compared with loglikelihood values obtained for a tree with no phylogenetic signal $(\lambda=0)$ using a likelihood ratio test as implemented by the package Geiger for $R$ ! [47].

Both statistics were based on the Bayesian consensus tree. Characters that showed significant phylogenetic signal $(K$ index $>1, P$ values $<0.01)$ were optimized as a means to visualize the character similarity between closely related taxa. The character optimizations were performed using parsimony over 800 trees selected from the resulting BI topologies, with the "Trace over trees" option in Mesquite. Given that this option only uses discrete character states, continuous characters were divided into three discrete ranges of low, intermediate, and high values. These ranges were established on the basis of the highest and lowest scores for each character across all taxa and were used to visualize the similarity between closely related taxa identified by the phylogenetic signal. All character state changes were treated as unordered, and the optimizations were plotted over the Bayesian consensus tree, thereby indicating the percentage of trees showing the unique best reconstruction for character states at each major node.

\section{Results}

3.1. Sequence Variations and Character Support Dynamics. Tests of partition homogeneity indicated no evidence for partition incongruence among both markers $(P=0.01)$ according to the recommendations of Cunningham [31], which indicated that combining both datasets decreases phylogenetic accuracy at $P<0.001$. Following the criteria used by Calcagnotto et al. [8], these results would, however, depart from the null hypothesis. These authors associated this incongruence with the different evolutionary dynamics of mitochondrial versus nuclear genomes. Notwithstanding, nuclear and mitochondrial data were combined in their study because the nodes were strongly supported, as indicated by the absence of negative partitioned branch support as in our study [48]. Combining our data resulted in a matrix of $1071 \mathrm{bp}$, of which 454 characters were variable and 308 were phylogenetically informative under parsimony.

3.2. Phylogenetic Trees. Separate Bayesian and parsimony analyses of the $16 \mathrm{~S}$ rDNA and the $18 \mathrm{~S}$ rDNA data were mostly congruent, with both approaches rendering very similar phylogenetic trees. In addition, the Bayesian analysis of the combined data produced a strongly supported topology that was congruent with trees from the separate analyses of the mitochondrial and nuclear data (Figure 4). Maximum Parsimony analysis of the combined data yielded two equally most parsimonious trees with lengths of 1,634 steps with a consistency index $(\mathrm{CI})=0.4168$ and a retention index $(\mathrm{RI})=$ 0.6692. Parsimony bootstrap proportions were generally lower for the deepest nodes, but the clades recognized in 


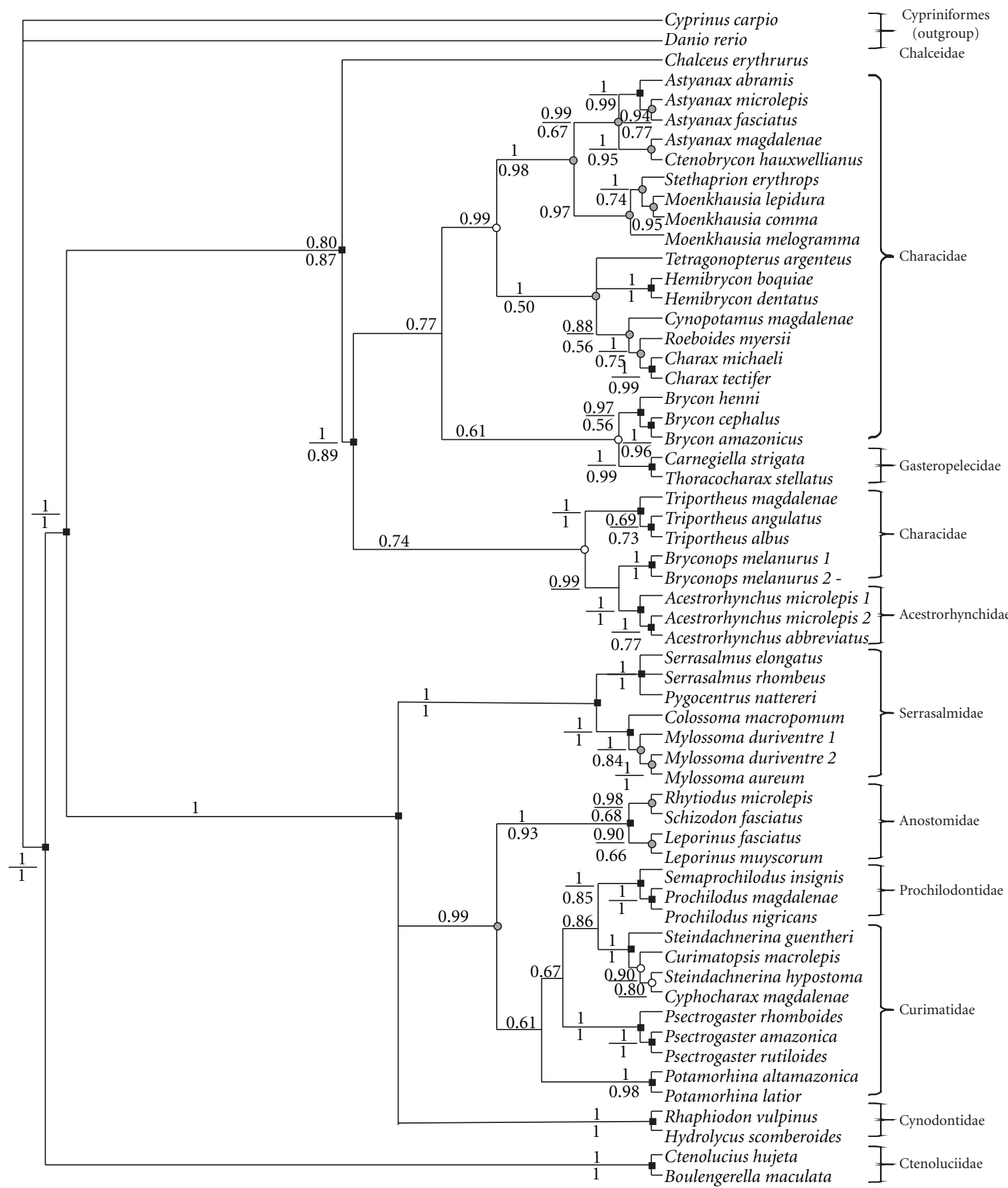

- mtDNA

- nucDNA

- Both

FIGURE 4: Phylogeny of the order Characiformes based on combined Bayesian analysis of 16S rDNA and 18S rDNA. Values above branches indicate Bayesian posterior probability (posterior probability $>0.5$ ), while those below branches indicate parsimony bootstrap proportions for concordant clades (bootstrap value $>50 \%$ ). Nodes that were also recovered in separate Bayesian analyses of mitochondrial and/or nuclear data are labeled with symbols. Unlabeled nodes were unique to combined data analysis. 


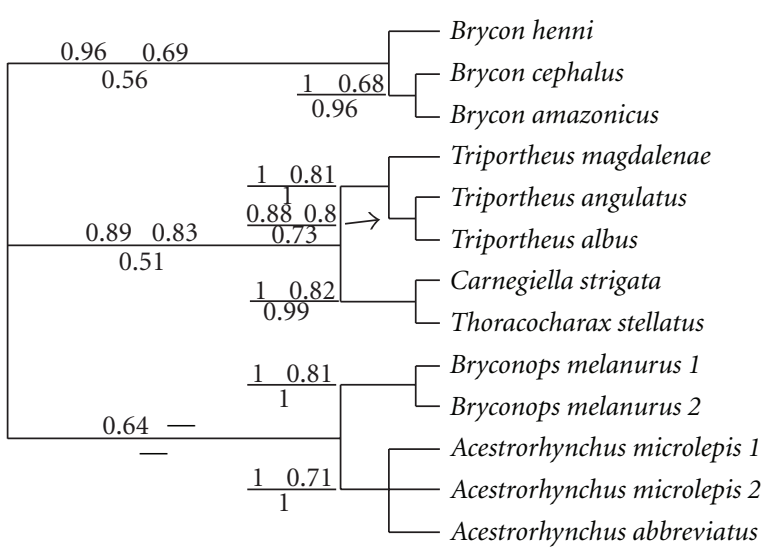

FIgURe 5: Relationships among the species of Triportheus and the family Gasteropelecidae. Numbers indicate posterior probability and bootstrap $(\geq 0.50)$ values for $16 \mathrm{~S}$ rDNA analyses (above line) and bootstrap value for combined data sets (below line) for each node.

previous molecular analyses $[8,9]$ and numerous morphological studies were strongly supported (Figure 4). Although the two haplotype reconstructions were equally feasible $(P=$ $0.376)$, the tree evaluations for combined data indicated that the Bayesian inference performed better than Maximum Parsimony inference (BI- $\operatorname{Ln} L=10,745.22$ versus MP- Ln $L=10,756.40$ ).

Despite the pronounced congruence between the Bayesian and Parsimony analyses, it is noteworthy that in both the $16 \mathrm{~S}$ rDNA and combined Maximum Parsimony analyses, the Gasteropelecidae grouped with Triportheus with moderately high branch support $(\mathrm{Pp}=0.89$ and $\mathrm{B}=0.83$ for $16 \mathrm{~S} \mathrm{rDNA}$, $\mathrm{B}=0.51$ for combined data, see Figure 5). Moreover, the Cynodontidae were resolved as the sister group of the cluster consisting of the Serrasalmidae, Anostomidae, Prochilodontidae, and Curimatidae in the Maximum Parsimony analysis of combined data. In recent studies $[8,9]$ these five families alternatively constituted a single supported clade as was the result in the Bayesian approach (Figure 4).

Our phylogenetic results are in many ways congruent with the results of previous phylogenetic reconstructions [6$10,49-51$ ], albeit with differences in the included species. As noted above, two well-supported main groups were observed (Figure 4) that contain the majority of members of the Characiformes. The first group included the Characidae, Acestrorhynchidae, and Gasteropelecidae. As in Calcagnotto et al. [8] and Javonillo et al. [9], the Acestrorhynchidae and Gasteropelecidae are included in a broad Characidae. This conclusion differs from the placement of the Acestrorhynchidae as the sister group of the Alestidae as per the molecular based hypothesis of Ortí and Meyer [6] or as the sister group of the Cynodontidae as suggested by Lucena and Menezes [52] based on morphological features. The Gasteropelecidae was found to be most closely related to the characid genus Brycon contrary to its placement as the sister group of the Anostomidae by Ortí and Meyer [6].

The second major lineage consists of three well-supported clades- the first being the Cynodontidae, the second the Serrasalmidae, and the third grouping consisting of what is now recognized as the Anostomidae, Curimatidae, and Prochilodontidae. Previous phylogenetic studies have demonstrated that each of these three families is monophyletic $[6,11]$, and these families plus the Chilodontidae (not analyzed in this study) form a monophyletic assemblage [49]. Contrary to previous studies, our results indicate that the Prochilodontidae falls within the Curimatidae rather than as the sister group to that family. The Ctenoluciidae resolved as a well-supported clade which is the sister group to all other examined characiforms. Previous studies $[7,8]$ alternatively proposed that the Ctenoluciidae is most closely related to either the Neotropical Lebiasinidae or the African Hepsetidae and Alestidae. None of those families were, however, included in this analysis.

The serrasalmids are considered to be a subfamily of the Characidae by many authors. Nevertheless, our results and some previous analyses (although supporting the hypothesis that the Serrasalmidae constitute a monophyletic group $[8,9$, $50,53])$ also indicate that they are more closely related to the Anostomidae, Curimatidae, and Prochilodontidae than to the remainder of what was traditionally considered to be the Characidae [8]. Therefore, although the relationship of serrasalmids to other families within the order Characiformes remains a subject of controversy it seems clear that the Serrasalmidae is a clade separate from the Characidae and for the purposes of this analysis is considered a separate family. Internal relationships within the Serrasalmidae should be interpreted with caution in so far as our aim was not a thorough phylogenetic analysis of the group. Yet, our results show a pacu clade of herbivores (Colossoma and Mylossoma) and a clade of piranhas (Serrasalmus and Pygocentrus), a result in agreement with that of Ortí et al. $[50,53]$ but not of Calcagnotto et al. [8].

Another difference involves Chalceus. In our analysis that genus is phylogenetically separated from the Characidae whereas other studies place it as a member of that family $[6,8]$ or sister to the Alestidae $[51,54]$. Interestingly, the very short base of the anal fin in Chalceus erythrurus highlighted by the CART analysis (Figure 6) contrasts with the long base of the anal fin that characterizes the Characidae of our analysis (Astyanax, Ctenobrycon, Stethaprion, Moenkhausia, Tetragonopterus, Hemibrycon, Cynopotamus, Roeboides, and Charax) and as such may be evidence that the relationships of Chalceus do lie outside of the Characidae, probably in the family Chalceidae.

Further support concerning the non-monophyly of the Characidae, supported by both the phylogeny and the CART analysis, involves the Gasteropelecidae and Triportheus. In both the 16S rDNA analyses and in the combined Maximum Parsimony analysis (Figure 5) and CART analysis (Figure 6) these taxa grouped together. Species of the Gasteropelecidae and Triportheus share a long pectoral fin and an ability to perform long jumps out of the water. In addition to serving as a mode to avoid predators, the overall modifications of the head, body, and fins permit them to efficiently prey on potential prey items at, or near, the water surface. Nonetheless, the Bayesian analysis did not show this association between the Gasteropelecidae and Triportheus (Figure 4) thereby raising 


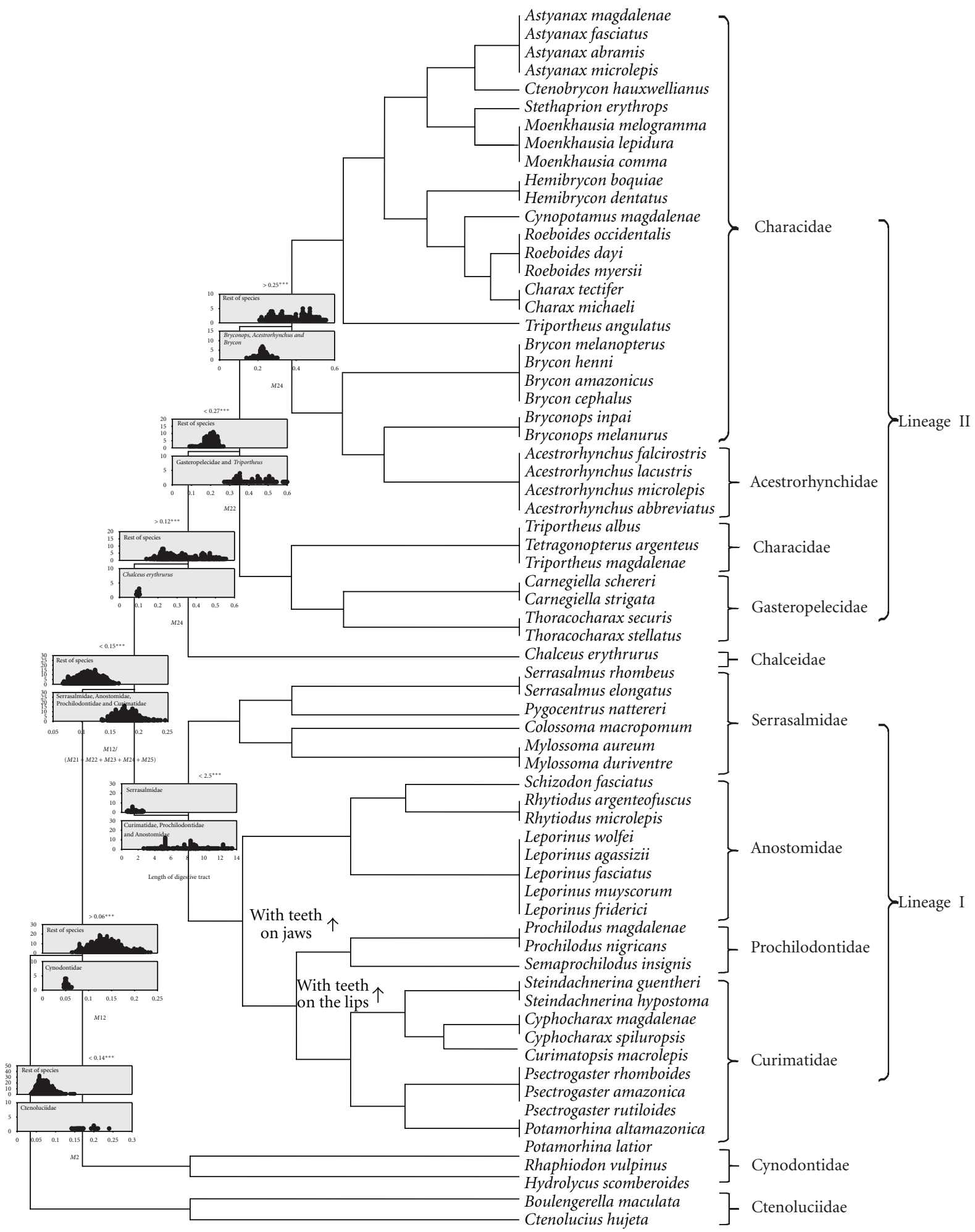

FIGURE 6: Tree obtained from CART analysis performed on morphological and trophic measurements of the species of the Characiformes analyzed in this study, indicating morphological measurements that discriminate each node and level of significance of differences observed for each morphological measurement at each node: $P<0.001$ (***) $^{*}$. 
questions as to their sister group relationship. Mirande [51] alternatively suggested that Triportheus is a member of the Bryconinae.

3.3. CART Analysis. The CART analysis resulted in the identification of variables that best discriminate the different nodes (Figure 6), based on their possible phylogenetic relationships. At all nodes, at least one character significantly discriminated each divergent lineage (Figure 6).

The proportion of the base of the dorsal fin relative to the dimensions of the other fins was an important morphological character that discriminates two major lineages, one including the Curimatidae, Prochilodontidae, Anostomidae, and Serrasalmidae (lineage I) and the other consisting of the Characidae, Acestrorhynchidae, and Gasteropelecidae (lineage II). The two clades differ in their trophicassociated morphology. All of the families in this lineage have been proposed to be monophyletic on the basis of a number of morphological synapomorphies and genetic data. A short digestive tract discriminates the Serrasalmidae from the Curimatidae, Prochilodontidae, and Anostomidae (Figure 6). The presence of teeth firmly implanted onto the jaws discriminates the Anostomidae from the Curimatidae plus Prochilodontidae, both of which lack such dentition. Finally, the main difference between the Curimatidae and Prochilodontidae was the absence of any oral dentition in the former family versus the presence of extensive series of mobile teeth implanted on the fleshy lips of the latter family (Figure 6). These, particularly the separation of the Curimatidae plus Prochilodontidae, correlate with some dramatic internal modifications detailed under the discussion below.

Lineage II includes two groups long recognized as monophyletic (Acestrorhynchidae and Gasteropelecidae) along with the Characidae which does not resolve as monophyletic in our results and which has long been recognized as an artificial assemblage in the taxonomic literature [6-10, 4951]. Notable differences in the size of pectoral and anal fins occur among the groups in this lineage and will be described in the discussion. As will be shown in the next section, there is trophic differentiation among the clades in this lineage in addition to the differentiation based on the size of anal and pectoral fins.

\subsection{Phylogenetic Signal and Character Optimization. Based} on the CART analysis, four characters were recovered as being important on the discrimination among clades, for which $K$-index showed a significant phylogenetic signal. All four are related to swimming and feeding habits. The $K$ values estimated for the relationship between the length of the dorsal fin and all other fins, as well as the length of the dorsal fin itself (M12), were all greater than 1, indicating a trend for closely related species to resemble one another more so than would be expected under a Brownian motion evolutionary model. The larger base of the dorsal fins is consistent across the Anostomidae, Curimatidae, Prochilodontidae, and Serrasalmidae, whereas the clade comprised of the Acestrorhynchidae, Characidae, and Gasteropelecidae has a tendency for the base of the dorsal fin to be smaller (Figure 7).

Habitat preference, although variable among most of the considered major groups, shows phylogenetic signal $(\lambda=$ $0.89, P$-value $<0.01)$. A general trend is for a predominance of members of the Acestrorhynchidae, Characidae, and Gasteropelecidae in fast-flowing environments such as creeks and streams $(54 \%$ of the studied species inhabit these habitats), whereas the species within the clade formed by the Anostomidae, Curimatidae, Prochilodontidae, and Serrasalmidae are characterized by a preference for environments of flow-flowing or still waters (Figure 8) such as lakes and/or swamps (49\%) and slower rivers (39\%).

Feeding-related characters with a significant phylogenetic signal and $K$-values greater than 1 include the length of the digestive tract and measurement M2. M2 is the distance from the midpoint of the upper jaw to the anterior margin of the eye with this distance, in turn, largely a function of alternative jaw forms. Character optimization indicates that larger values for the length of the digestive tract are in the families Curimatidae and Prochilodontidae (Figure 9) which jointly form a clade of detritivorous fish $[55,56]$. Curimatidae plus Prochilodontidae form a monophyletic unit as evidenced by a number of modifications of the gill arches and associated structures (e.g., the muscular epibranchial organs above the gill arches) which are unique to these families within the Characiformes [49].

Tooth type also demonstrates a significant phylogenetic signal $(\lambda=1$, Figure 10$)$. Interfamilial highly divergent, albeit intrafamilial homogeneous modifications of the dentition characterize examined members of the Anostomidae, all of which had flat teeth, the species of the Prochilodontidae which have in common small villiform teeth attached to the lips and the members of the Curimatidae which lack oral dentition other than as larvae. Multicuspid dentition is probably associated with omnivorous feeding habits and teeth of this morphology are present in the genera Astyanax, Ctenobrycon, Stethaprion, Moenkhausia, Tetragonopterus, and Hemibrycon [57-61]. The families Cynodontidae and Ctenoluciidae with carnivorous habits $[60,62]$ and canine teeth form the sister group to the other characiforms in this analysis.

\section{Discussion}

The evidence indicates that the families of Neotropical characiforms analyzed in this study (Acestrorhynchidae, Anostomidae, Characidae, Ctenoluciidae, Curimatidae, Cynodontidae, Gasteropelecidae, Prochilodontidae, and Serrasalmidae) first shifted into different macrohabitats followed by morphological diversification in characters seemingly related to differences in trophic niches. This model of diversification is very similar to that proposed by Danley and Kocher [63] for the adaptive radiation of cichlids in Lake Malawi and further explored by Streelman and Danley [64]. This model has since been supported by numerous studies of cichlids as well as of radiations among parrotfishes [65] 


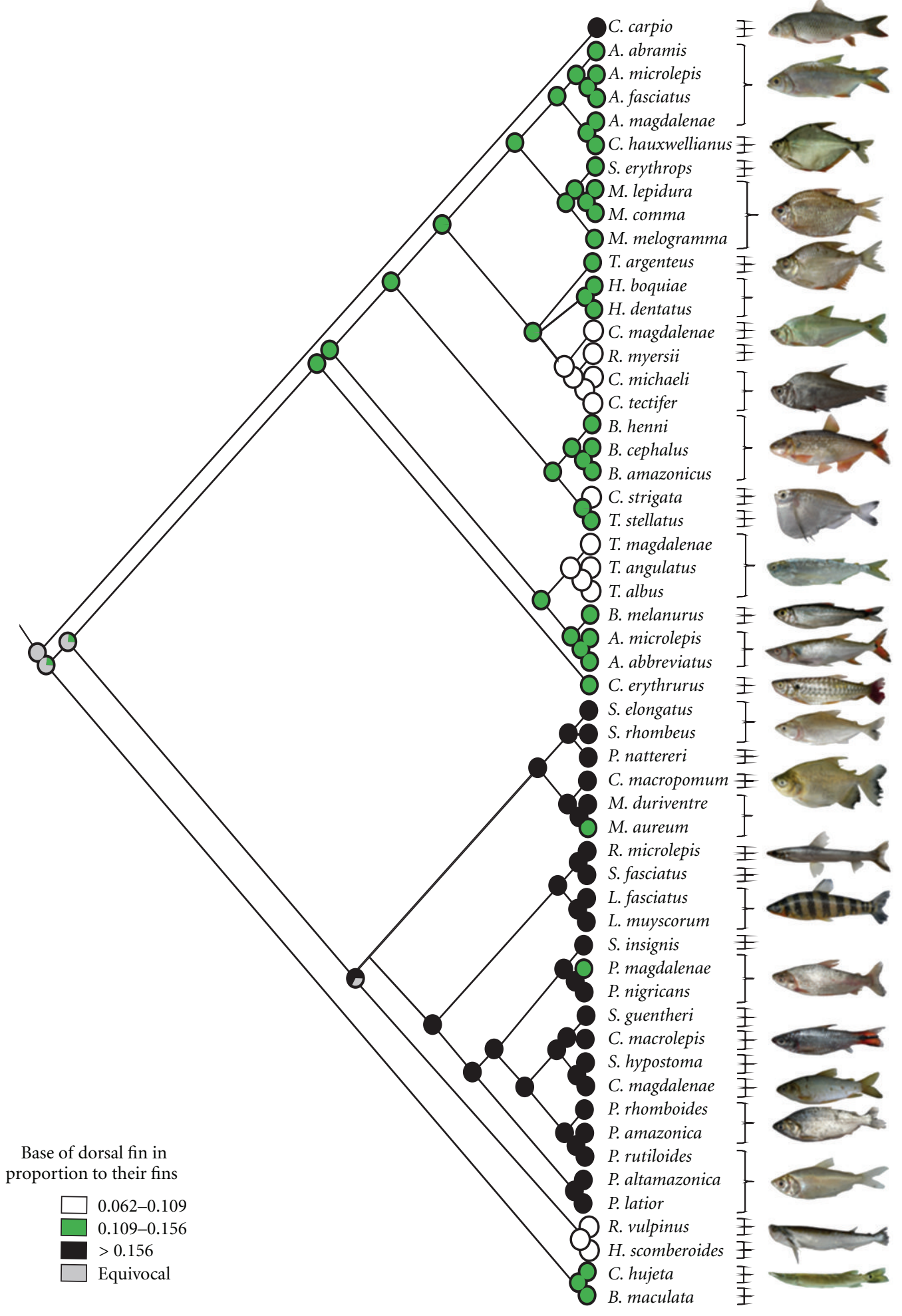

Figure 7: Reconstruction of size of dorsal fin in proportion to other fins shown on consensus tree in 800 trees with Bayesian inference. Pie charts at major nodes show posterior probabilities from stochastic analysis of ancestral state reconstructions assuming that character-state evolution is unordered. 


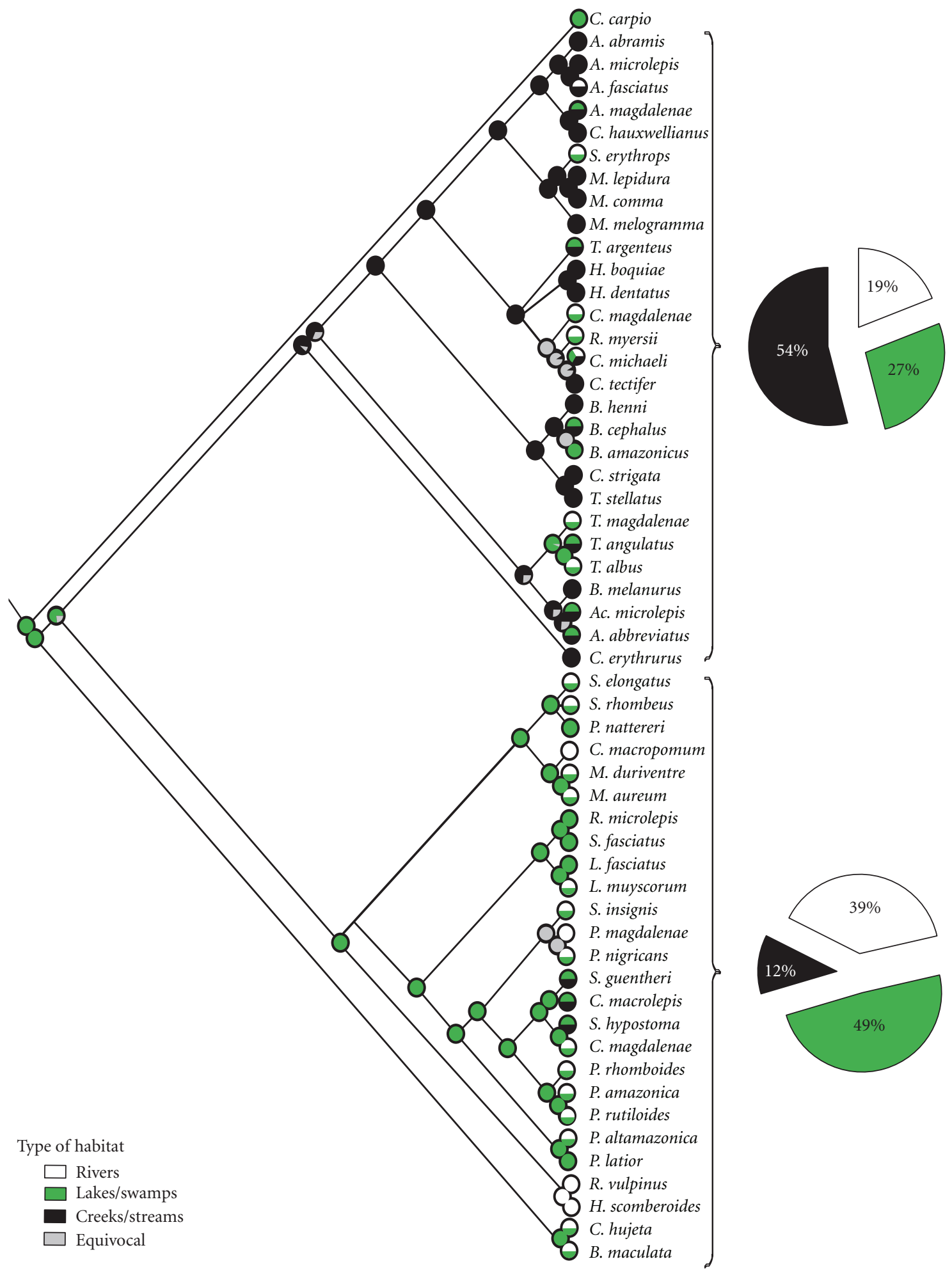

FigURE 8: Reconstruction of habitat shown on consensus tree in 800 trees with Bayesian inference. Pie charts at major nodes show posterior probabilities from stochastic analysis of ancestral state reconstructions assuming that character-state evolution is unordered. 


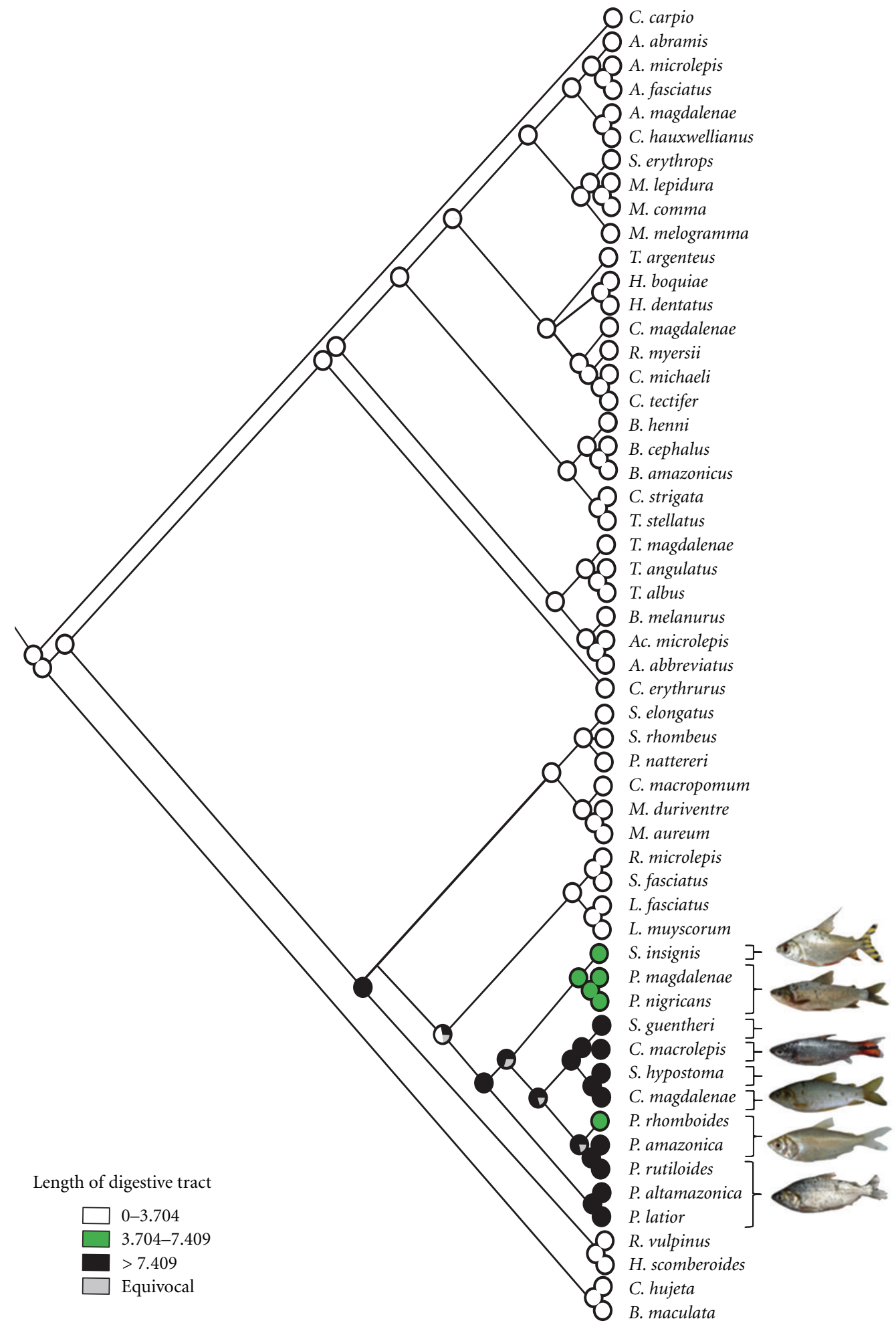

FIGURE 9: Reconstruction of digestive tract shown on consensus tree in 800 trees with Bayesian inference. Pie charts at major nodes show posterior probabilities from stochastic analysis of ancestral state reconstructions, assuming that character-state evolution is unordered. 


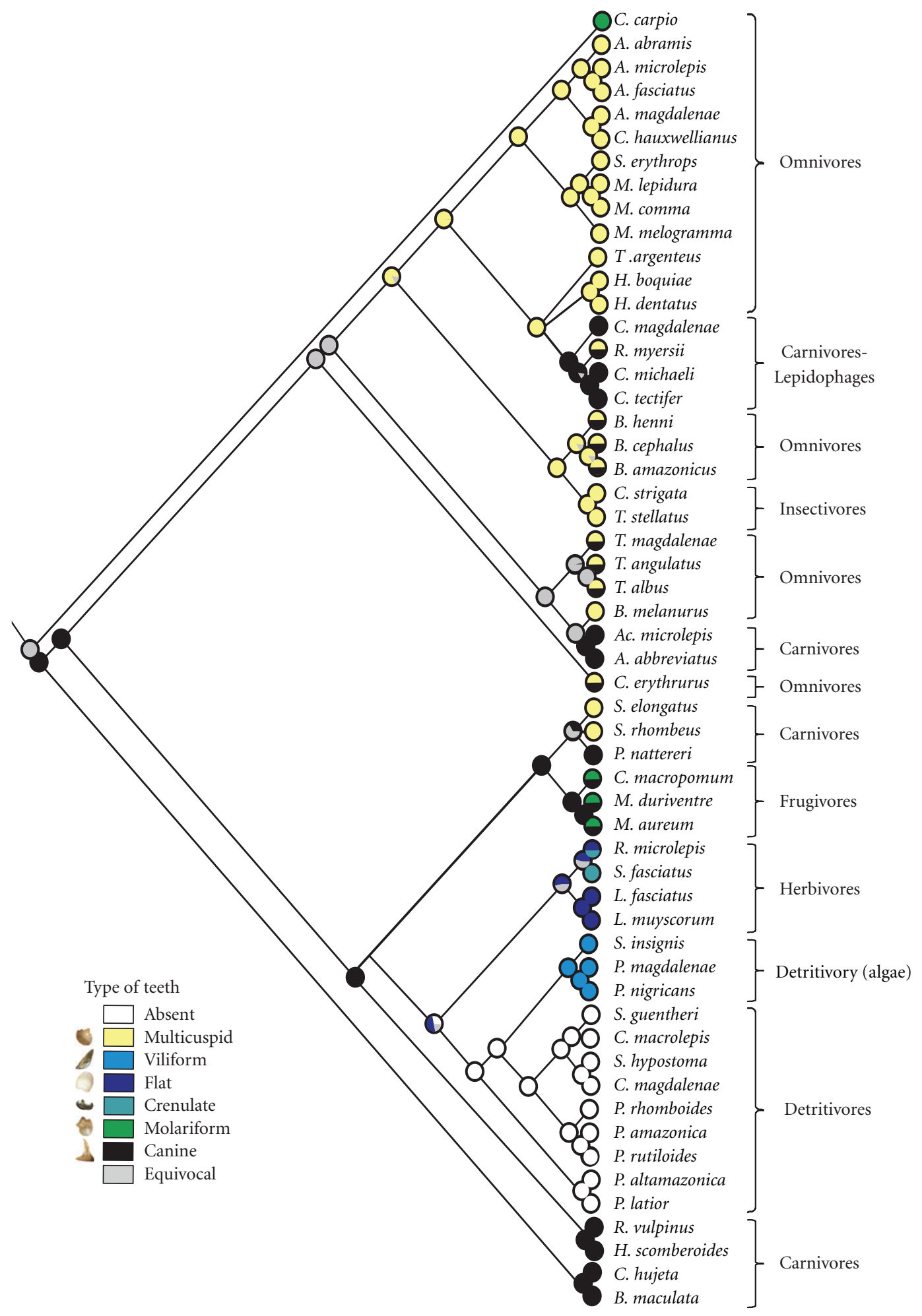

FIGURE 10: Reconstruction of teeth type shown on consensus tree in 800 trees with Bayesian inference. Pie charts at major nodes show posterior probabilities from stochastic analysis of ancestral state reconstructions assuming that character-state evolution is unordered. 
and gobies [66] in marine waters. Disruptive sexual selection is proposed in this model based upon nuptial coloration as stage III of the diversification process. In our study it was not possible to investigate the role of sexual selection in triggering early divisions since the reconstructed relationships among ingroup taxa cannot be taken as definitive specieslevel phylogenetic hypotheses due to the low number of species analyzed within some genera and/or the low number of genera analyzed within some speciose families.

Characiforms with a relatively large dorsal-fin base relative to other fins (Anostomidae, Curimatidae, Prochilodontidae, and Serrasalmidae) inhabit primarily lakes, swamps, and rivers in the analysis, whereas species with a short dorsal-fin base (Acestrorhynchidae, Characidae, and Gasteropelecidae) inhabit mainly creeks and streams (Figures 7 and 8). The dorsal fin plays an important role during swimming and maneuvering although it is difficult to parse out the critical component for our analysis in light of the multifunctionality of that and other fins $[67,68]$.

Nonetheless, studies have demonstrated that the dorsal fin is acted upon by fluid forces that promote rolling movements of the body [68]. Although the anal fin may also play an important role in preventing such rolling, some studies have shown that at all speeds and in all maneuvers, the area of the dorsal fin is greater than that of the anal fin [69]. As such a small dorsal fin which reduces drag should be functionally advantageous for life in the higher energy setting of fast water habitats.

The length of the dorsal-fin base reflects the total number of branched plus unbranched rays in the fin. Malabarba and Weitzman [70] utilized that feature to unite a major clade within the Characidae which they termed Clade A and this clade later was supported by the molecular phylogenetic study of Javonillo et al. [9]. It is noteworthy that the African characiform family Distichodontidae identified by S. V. Fink and W. L. Fink [36] as basal within the Characiformes includes a number of species and genera with relatively high numbers of dorsal-fin rays and correlated long dorsal-fin bases. Although not part of that study, the members of that family with long dorsal-fin bases also tend to occur in habitats comparable to those occupied by their South American characiform counterparts with that condition.

The results of this study indicate that the shift into different major macrohabitats was followed by trophic segregation among clades. In the lineage formed by the Curimatidae, Prochilodontidae, Anostomidae, and Serrasalmidae there was clear food segregation into detritivores (Curimatidae, Prochilodontidae), herbivores (Anostomidae), and carnivores (Serrasalmidae) $[58,59,71-73]$. The length of the digestive tract is notably longer in groups such as the Curimatidae and Prochilodontidae feeding on detritus and biofilm (Figure 9). Functionally, the long intestine can be explained by the fact that some of the components of that diet are harder to digest, thereby requiring both a longer passage time and a large area for processing and absorption [56]. Most species of the Curimatidae evolved to a benthic detritivorous diet [74] and display adaptations including the lack of teeth, the presence of a well-developed epibranchial organ, and a long intestine, all modifications which correlate with benthic feeding [75]. Species of the family Prochilodontidae primarily consume fine and flocculent detritus and biofilm, both of which consist of varying amounts of organic particles, algae, microinvertebrates, and inorganic sediments which these fish gather from the surface of subaquatic plants and submerged items [76] using their highly modified teeth and jaws. The villiform teeth of the family Prochilodontidae are useful for scraping periphyton [76].

Those and the evertible suctorial jaws of that family also serve to ingest organic sediments which settle onto sur-faces from the water column and the algae and benthic macroinvertebrates attached to or living on subaquatic surfaces. As in the Curimatidae, the epibranchial organ in the Prochilodontidae serves to concentrate these times within the oral cavity before they are passed to the esophagus [49].

The family Anostomidae shows some variation in food habits. Literature information indicates that Schizodon fasciatus primarily exploits the vegetative parts of higher plants with this sometimes supplemented with algae [71]. Rhytiodus has a diet mainly composed of aquatic macrophytes and was similarly classified as a herbivore [77]. The species of Abramites are omnivores that feed primarily on aquatic invertebrates and vegetation [78]. Finally, species of Leporinus are generally omnivores [79].

Tooth morphology also showed a significant phylogenetic signal (Figure 10). Different types of teeth found in the lineages of the order Characiformes showed consistent trends for some types of teeth and a clear association with the types of foods reported to be exploited by these groups (Figure 10). The family Characidae typically has a moderate-to-large-sized maxillae bearing dentition. The premaxilla consistently has the greatest number of teeth in the upper jaw across the Characiformes and demonstrates a pronounced range in dentition. Variables include the presence versus absence of teeth, their mode of attachment (directly to the premaxilla versus to the overlying lip), the relative size of the teeth, the number of rows of teeth (one to three), the number of teeth in each tooth row, and in particular the range in the form of the dentition. This range encompasses conical dentition sometimes developed into canines to increasingly complicated multicuspid teeth that differ in the form and number of cusps. In some instances the dentition even extends onto the outer surface of the jaws as is the case in the lepidophagus Roeboides which uses its external mammiliform dentition to remove scales from prey. The lower jaw demonstrates a comparable pronounced variation in the number of tooth rows, numbers of teeth, and their form.

Differences in body form also align with phylogenetic groupings, a not unexpected finding since closely related species typically have in common similar diets that require comparable food acquisition strategies (e.g., carnivory versus detritivory), locations within the water column (near surface, mid-column and benthic), and feeding patterns (e.g., grazing versus ambush predation). A prime example of how morphological modifications permit exploitation of particular food items is the species of the family Gasteropelecidae that feed almost entirely on allochthonous insects which fall on the water surface [80-82]. The upturned mouths 
in the Gasteropelecidae permit them to readily feed on that abundant food source and their dramatically expanded pectoral fins and associated muscles that attach onto the expanded pectoral girdle allow them to perform long and high jumps out of the water [81] in order to escape predators.

In summary, habitat and morphological trophic segregation appear to have been major factors explaining the differences among the major clades obtained in the phylogenetic analysis of Neotropical members of the Characiformes. The most significant habitat segregation was that between species which mainly inhabit lakes, swamps, and rivers versus those species that primarily inhabit creeks and streams. Families also differ in the presence versus absence and type of teeth.

\section{Acknowledgments}

This study was supported by the AMAPEZ project (CGL2006-02155 BOS) of the MEC (Ministry of Education and Science) under FEDER funds from the XUNTA de Galicia and by contributions from the Universidad de Vigo, the Universidad de Antioquia, and the Universidad Nacional de Colombia. A. Manjarrés-Hernández gratefully acknowledges a grant from COLCIENCIAS. The authors wish to thank J. M. Matías and Emma Janeiro for help with the CARTs, GAIA for their help during sampling in Ayapel, and Ricardo Callejas for his help with the evolutionary studies.

\section{References}

[1] R. H. Lowe-McConnell, Ecological Studies in Tropical Fish Communities, Cambridge University Press, Cambridge, UK, 1987.

[2] C. Sturmbauer, "Explosive speciation in cichlid fishes of the African Great Lakes: a dynamic model of adaptive radiation," Journal of Fish Biology, vol. 53, pp. 18-36, 1998.

[3] R. C. Albertson, J. A. Markert, P. D. Danley, and T. D. Kocher, "Phytogeny of a rapidly evolving clade: the cichlid fishes of Lake Malawi, East Africa," Proceedings of the National Academy of Sciences of the United States of America, vol. 96, no. 9, pp. 5107-5110, 1999.

[4] C. Guisande, A. Manjarrés-Hernández, P. Pelayo-Villamil et al., "IPez: an expert system for the taxonomic identification of fishes based on machine learning techniques," Fisheries Research, vol. 102, no. 3, pp. 240-247, 2010.

[5] R. P. Vari and L. Malabarba, "Neotropical ichthyology: an overview," in Phylogeny and Classification of Neotropical Fishes, L. Malabarba, R. Reis, R. Vari, Z. Lucena, and C. Lucena, Eds., Conselho Editorial EDIPUCRS, Porto Alegre, Brazil, 1998.

[6] G. Ortí and A. Meyer, "The radiation of characiform fishes and the limits of resolution of mitochondrial ribosomal DNA sequences," Systematic Biology, vol. 46, no. 1, pp. 75-100, 1997.

[7] P. A. Buckup, "Relationships of the Characidiinae and phylogeny of characiform fishes (Teleostei: Characiformes)," in phylogeny and Classification of Neotropical Fishes, L. R. Malabarba, R. E. Reis, R. P. Vari et al., Eds., pp. 193-234, EDIPUCRS, Porto Alegre, Brazil, 1998.

[8] D. Calcagnotto, S. A. Schaefer, and R. DeSalle, "Relationships among characiform fishes inferred from analysis of nuclear and mitochondrial gene sequences," Molecular Phylogenetics and Evolution, vol. 36, no. 1, pp. 135-153, 2005.
[9] R. Javonillo, L. R. Malabarba, S. H. Weitzman, and J. R. Burns, "Relationships among major lineages of characid fishes (Teleostei: Ostariophysi: Characiformes), based on molecular sequence data," Molecular Phylogenetics and Evolution, vol. 54, no. 2, pp. 498-511, 2010.

[10] C. Oliveira, G. S. Avelino, K. T. Abe et al., "Phylogenetic relationships within the speciose family Characidae (Teleostei: Ostariophysi: Characiformes) based on multilocus analysis and extensive ingroup sampling," BMC Evolutionary Biology, vol. 11, no. 1, article 275, 2011.

[11] P. A. Buckup, The Characidiinae: a phylogenetic study of the South American darters and their relationships with other characiform fishes, Ph.D. dissertation, University of Michigan, Ann Arbor, Mich, USA, 1991.

[12] J. Marcos Mirande, "Weighted parsimony phylogeny of the family Characidae (Teleostei: Characiformes)," Cladistics, vol. 25, no. 6, pp. 574-613, 2009.

[13] B. Sidlauskas, "Testing for unequal rates of morphological diversification in the absence of a detailed phylogeny: a case study from characiform fishes," Evolution, vol. 61, no. 2, pp. 299-316, 2007.

[14] B. Sidlauskas, "Continuous and arrested morphological diversification in sister clades of characiform fishes: a phylomorphospace approach," Evolution, vol. 62, no. 12, pp. 3135-3156, 2008.

[15] B. L. Sidlauskas and R. P. Vari, "Phylogenetic relationships within the South American fish family Anostomidae (Teleostei, Ostariophysi, Characiformes)," Zoological Journal of the Linnean Society, vol. 154, no. 1, pp. 70-210, 2008.

[16] J. Sambrook, E. F. Fritsch, and T. Maniatis, Molecular Cloning: A Laboratory Manual, Cold Spring Harbor Lab Press, New York, NY, USA, 1989.

[17] S. M. Degnan, "The perils of single-gene trees-mitochondrial versus single-copy nuclear-DNA variation in white-eyes (Aves, Zosteropidae)," Molecular Ecology, vol. 2, pp. 219-225, 1993.

[18] S. R. Palumbi and C. S. Baker, "Contrasting population structure from nuclear intron sequences and mtDNA of humpback whales," Molecular Biology and Evolution, vol. 11, no. 3, pp. 426-435, 1994.

[19] J. Avise, Phylogeography: The History and Formation of Species, Harvard University Press, London, UK, 2000.

[20] S. R. Palumbi, A. P. Martin, S. R. Romano et al., The Simple Fool's Guide to PCR (ver. 2.0), Department of Zoology, University of Hawaii Special Publication, Honolulu, Hawaii, 1991.

[21] S. Rozenand and H. Skaletsky, "Primer3 on the WWW for general users and for biologist programmers," in Bioinformatics Methods and Protocols: Methods in Molecular Biology, S. Krawetz and S. E. Misener, Eds., pp. 365-386, Humana Press, Totowa, NJ, USA, 2000.

[22] J. D. Thompson, T. J. Gibson, F. Plewniak, F. Jeanmougin, and D. G. Higgins, "The CLUSTAL X windows interface: flexible strategies for multiple sequence alignment aided by quality analysis tools," Nucleic Acids Research, vol. 25, no. 24, pp. 4876-4882, 1997.

[23] K. Tamura, J. Dudley, M. Nei, and S. Kumar, "MEGA4: Molecular Evolutionary Genetics Analysis (MEGA) software version 4.0," Molecular Biology and Evolution, vol. 24, no. 8, pp. 1596-1599, 2007.

[24] D. Posada and K. A. Crandall, "MODELTEST: testing the model of DNA substitution," Bioinformatics, vol. 14, no. 9, pp. 817-818, 1998.

[25] H. Akaike, "New look at statistical-model identification," IEEE Transactions on Automatic Control, vol. 19, no. 6, pp. 716-723, 1974. 
[26] J. S. Farris, M. Kallersjo, A. G. Kluge et al., "Testing significance of incongruence," Cladistics, vol. 10, no. 1, pp. 315-319, 1994.

[27] D. L. Swofford, PAUP. Phylogenetic Analysis Using Parsimony (and other methods), version 4, Sinauer Associates, Sunderland, Mass, USA, 2000.

[28] D. J. Eernisse and A. G. Kluge, "Taxonomic congruence versus total evidence, and amniote phylogeny inferred from fossils, molecules, and morphology," Molecular Biology and Evolution, vol. 10, no. 6, pp. 1170-1195, 1993.

[29] I. P. Farias, G. Ortí, and A. Meyer, "Total evidence: molecules, morphology, and the phylogenetics of cichlid fishes," Journal of Experimental Zoology, vol. 288, no. 1, pp. 76-92, 2000.

[30] F. G. R. Liu and M. M. Miyamoto, "Phylogenetic assessment of molecular and morphological data for eutherian mammals," Systematic Biology, vol. 48, no. 1, pp. 54-64, 1999.

[31] C. W. Cunningham, "Can three incongruence tests predict when data should be combined?" Molecular Biology and Evolution, vol. 14, no. 7, pp. 733-740, 1997.

[32] J. J. Wiens, "Combining data sets with different phylogenetic histories," Systematic Biology, vol. 47, no. 4, pp. 568-581, 1998.

[33] J. P. Huelsenbeck and F. Ronquist, "MRBAYES: bayesian inference of phylogenetic trees," Bioinformatics, vol. 17, no. 8, pp. 754-755, 2001.

[34] F. Ronquist and J. P. Huelsenbeck, "MrBayes 3: bayesian phylogenetic inference under mixed models," Bioinformatics, vol. 19, no. 12, pp. 1572-1574, 2003.

[35] J. Felsenstein, "Confidence limits on phylogenies: an approach using the bootstrap," Evolution, vol. 39, no. 4, pp. 783-791, 1985.

[36] S. V. Fink and W. L. Fink, "Interrelationships of the ostariophysan fishes (Teleostei)," Zoological Journal of the Linnean Society, vol. 72, no. 4, pp. 297-353, 1981.

[37] H. Shimodaira and M. Hasegawa, "Multiple comparisons of log-likelihoods with applications to phylogenetic inference," Molecular Biology and Evolution, vol. 16, no. 8, pp. 1114-1116, 1999.

[38] L. Breiman, J. Friedman, R. Olshen et al., Classification and Regression Trees, Wadsworth, 1984.

[39] W.-Y. Loh, "Classification and regression tree methods," in Encyclopedia of Statistics in Quality and Reliability, F. Ruggeri, R. Kenett, and F. Faltin, Eds., pp. 315-323, Wiley, 2008.

[40] T. Hastie, R. Tibshirani, and J. Friedman, The Elements of Statistical Learning. Data Mining, Inference and Prediction, Springer, 2001.

[41] W. Ñ. Venables and B. D. Ripley, Modern Applied Statistics with $S$, Springer, 2002.

[42] C. Guisande, A. Vaamonde, and A. Barreiro, Tratamiento de Datos, Díaz de Santos, Madrid, Spain, 2010.

[43] S. P. Blomberg, T. Garland, and A. R. Ives, "Testing for phylogenetic signal in comparative data: behavioral traits are more labile," Evolution, vol. 57, no. 4, pp. 717-745, 2003.

[44] R Development Core Team, "R: a language and environment for statistical computing. R Foundation for Statistical Computing," Vienna, Austria, 2009, http://www.r-project.org/.

[45] S. W. Kembel, D. D. Ackerly, S. P. Blomberg et al., "picante: $\mathrm{R}$ tools for integrating phylogenies and ecology," R package version 0.7-0, 2009, http://picante.r-forge.r-project.org.

[46] M. Pagel, "Inferring the historical patterns of biological evolution," Nature, vol. 401, no. 6756, pp. 877-884, 1999.

[47] L. Harmon, J. Weir, C. Brock, R. Glor, W. Challenger, and G. Hunt, "geiger: Analysis of evolutionary diversification," R package version 1.3-1, 2009.
[48] J. Gatesy, P. O’Grady, and R. H. Baker, "Corroboration among data sets in simultaneous analysis: hidden support for phylogenetic relationships among higher level artiodactyl taxa," Cladistics, vol. 15, no. 3, pp. 271-313, 1999.

[49] R. P. Vari, "Phylogenetic relationships of the families Curimatidae, Prochilodontidae, Anostomidae, and Chilodontidae," Smithsonian Contributions to Zoology, vol. 378, no. 1, pp. $1-60,1983$.

[50] G. Ortí, A. Sivasundar, K. Dietz, and M. Jégu, "Phylogeny of the Serrasalmidae (Characiformes) based on mitochondrial DNA sequences," Genetics and Molecular Biology, vol. 31, no. 1, pp. 343-351, 2008.

[51] J. M. Mirande, "Phylogeny of the family characidae (teleostei: Characiformes): from characters to taxonomy," Neotropical Ichthyology, vol. 8, no. 3, pp. 385-568, 2010.

[52] C. A. S. Lucena and N. E. Menezes, "A phylogenetic analysis of Roestes Günther and Gilbertolus Eigenmann, with a hypothesis on the relationships of the Cynodontidae and Acestrorhynchidae (Teleostei: Ostariophysi: Characiformes)," in Phylogeny and Classification of Neotropical Fishes, L. R. Malabarba, R. E. Reis, R. P. Vari et al., Eds., pp. 261-278, EDIPUCRS, Porto Alegre, Brazil, 1998.

[53] G. Ortí, P. Petry, J. I. R. Porto, M. Jégu, and A. Meyer, "Patterns of nucleotide change in mitochondrial ribosomal RNA genes and the phylogeny of piranhas," Journal of Molecular Evolution, vol. 42, no. 2, pp. 169-182, 1996.

[54] A. M. Zanata and R. P. Vari, "The family Alestidae (Ostariophysi, Characiformes): a phylogenetic analysis of a transAtlantic clade," Zoological Journal of the Linnean Society, vol. 145, no. 1, pp. 1-144, 2005.

[55] A. S. Flecker, "Ecosystem engineering by a dominant detritivore in a diverse tropical stream," Ecology, vol. 77, no. 6, pp. 1845-1854, 1996.

[56] R. M. C. Castro and R. P. Vari, "Detritivores of the South American fish family Prochilodontidae Teleostei: Ostariophysi: Characiformes): a phylogenetic and revisionary study," Smithsonian Contributions to Zoology, vol. 622, pp. 1-189, 2004.

[57] M. Goulding, The Fishes and the Forest: Explorations in the Amazonian Natural History, University of California Press, Berkeley, Calif, USA, 1980.

[58] J. Géry, Characoids of the World, T.F.H. Publications, Neptune, NJ, USA, 1977.

[59] N. S. Hahn, A. A. Agostinho, L. C. Gomes, and L. M. Bini, "Estrutura trófica da ictiofauna do reservatório: De Itaipu (Paraná-Brazil) nos Primeiros Anos de sua Formação," Interciencia, vol. 23, no. 5, pp. 299-305, 1998.

[60] C. Castellanos, Distribución especial de la comunidad de peces en una quebrada de aguas negras amazónicas, Leticia, Colombia, Tesis de pregrado, Biología, Universidad Nacional de Colombia, Bogotá, Colombia, 2002.

[61] G. Galvis, J. Mojica, S. Duque et al., "Peces del medio Amazonas. Región de Leticia," Conservación Internacional, serie de guías tropicales de campo 5, 2006.

[62] V. L. L. De Almeida, N. S. Hahn, and A. E. A. D. M. Vazzoler, "Feeding patterns in five predatory fishes of the high Paraná River floodplain (PR, Brazil)," Ecology of Freshwater Fish, vol. 6, no. 3, pp. 123-133, 1997.

[63] P. D. Danley and T. D. Kocher, "Speciation in rapidly diverging systems: lessons from Lake Malawi," Molecular Ecology, vol. 10, no. 5, pp. 1075-1086, 2001.

[64] J. T. Streelman and P. D. Danley, "The stages of vertebrate evolutionary radiation," Trends in Ecology and Evolution, vol. 18 , no. 3, pp. 126-131, 2003. 
[65] J. T. Streelman, M. Alfaro, M. W. Westneat, D. R. Bellwood, and S. A. Karl, "Evolutionary history of the parrotfishes: biogeography, ecomorphology, and comparative diversity," Evolution, vol. 56, no. 5, pp. 961-971, 2002.

[66] L. Rüber, J. L. Van Tassell, and R. Zardoya, "Rapid speciation and ecological divergence in the American seven-spined gobies (Gobiidae, Gobiosomatini) inferred from a molecular phylogeny," Evolution, vol. 57, no. 7, pp. 1584-1598, 2003.

[67] R. M. N. Alexander, Functional Design of Fishes, Hutchinson and Co., London, UK, 1967.

[68] D. H. Evans and J. B. Clauborne, The Physiology of Fishes, C. R. C. Press, 2006.

[69] E. M. Standen and G. V. Lauder, "Dorsal and anal fin function in bluegill sunfish Lepomis macrochirus: three-dimensional kinematics during propulsion and maneuvering," Journal of Experimental Biology, vol. 208, no. 14, pp. 2753-2763, 2005.

[70] L. R. Malabarba and S. H. Weitzman, "Description of a new genus with six new species from southern Brazil, Uruguay and Argentina, with a discussion of a putative characid clade (Teleostei: Characiformes: Characidae)," Comunicações do Museu de Ciências e Tecnologia, vol. 16, no. 1, pp. 67-151, 2003.

[71] B. de Mérona and J. Rankin-de-Mérona, "Food resource partitioning in a fish community of the central Amazon floodplain," Neotropical Ichthyology, vol. 2, no. 2, pp. 75-84, 2004.

[72] E. A. Luiz, A. A. Agostinho, L. C. Gomes, and N. S. Hahn, "Ecologia trófica de peixes em riachos da bacia do rio Paraná," Revista Brazileira de Biologia, vol. 58, pp. 273-285, 1998.

[73] L. G. Nico and D. C. Taphorn, "Food habits of piranhas in the low llanos of Venezuela," Biotropica, vol. 20, no. 4, pp. 311$321,1988$.

[74] R. P. Vari, "A phylogenetic study of the Neotropical characiform family Curimatidae (Pisces: Ostariophysi)," Smithsonian Contributions to Zoology, vol. 471, pp. 1-71, 1989.

[75] M. Pouilly, F. Lino, J. G. Bretenoux, and C. Rosales, "Dietarymorphological relationships in a fish assemblage of the Bolivian Amazonian floodplain," Journal of Fish Biology, vol. 62, no. 5, pp. 1137-1158, 2003.

[76] R. Fugi, N. S. Hahn, and A. A. Agostinho, "Feeding styles of five species of bottom-feeding fishes of the high Paraná River," Environmental Biology of Fishes, vol. 46, no. 3, pp. 297-307, 1996.

[77] R. Neves Dos Santos, E. J. G. Ferreira, and S. Amadio, "Effect of seasonality and trophic group on energy acquisition in Amazonian fish," Ecology of Freshwater Fish, vol. 17, no. 2, pp. 340-348, 2008.

[78] D. Taphorn, "The characiform fishes of the Apure River drainage," Biollania no. 4, Guanare, Venezuela, 1992.

[79] G. J. Galvis, J. I. Mojica, S. Duque et al., "Peces del medio Amazonas Región del Leticia," Conservación Internacional, serie de guías tropicales de campo 5, Bogotá, Colombia, 2006.

[80] A. L. Netto-Ferreira, M. P. Albrecht, J. L. Nessimian, and E. P. Caramaschi, "Feeding habits of Thoracocharax stellatus (Characiformes: Gasteropelecidae) in the upper rio Tocantins, Brazil," Neotropical Ichthyology, vol. 5, no. 1, pp. 69-74, 2007.

[81] S. H. Weitzman and L. Palmer, "Do freshwater hatchetfishes really fly?” Tropical Fish Hobbyist, vol. 45, no. 1, pp. 195-206, 1996.

[82] S. H. Weitzman and L. Palmer, "Family Gasteropelecidae," in Checklist of the Freshwater fishes of South and Central America, R. E. Reis, S. O. Kullander, and C. Ferraris Jr., Eds., pp. 101103, Edipucrs, Porto Alegre, Brazil, 2003. 

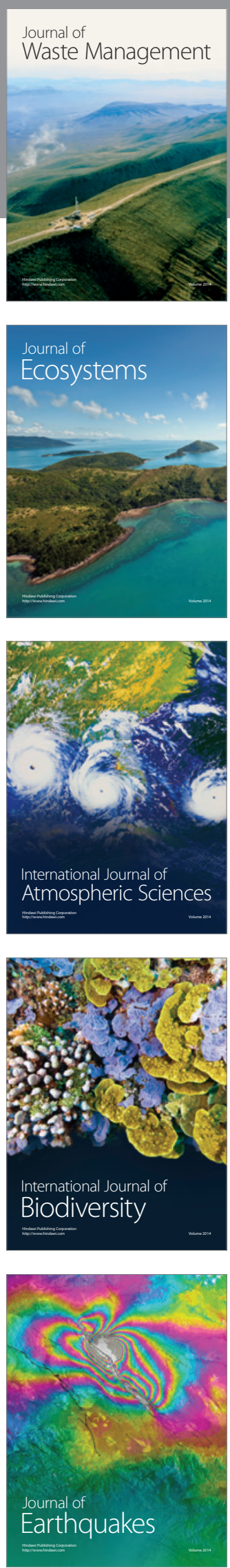
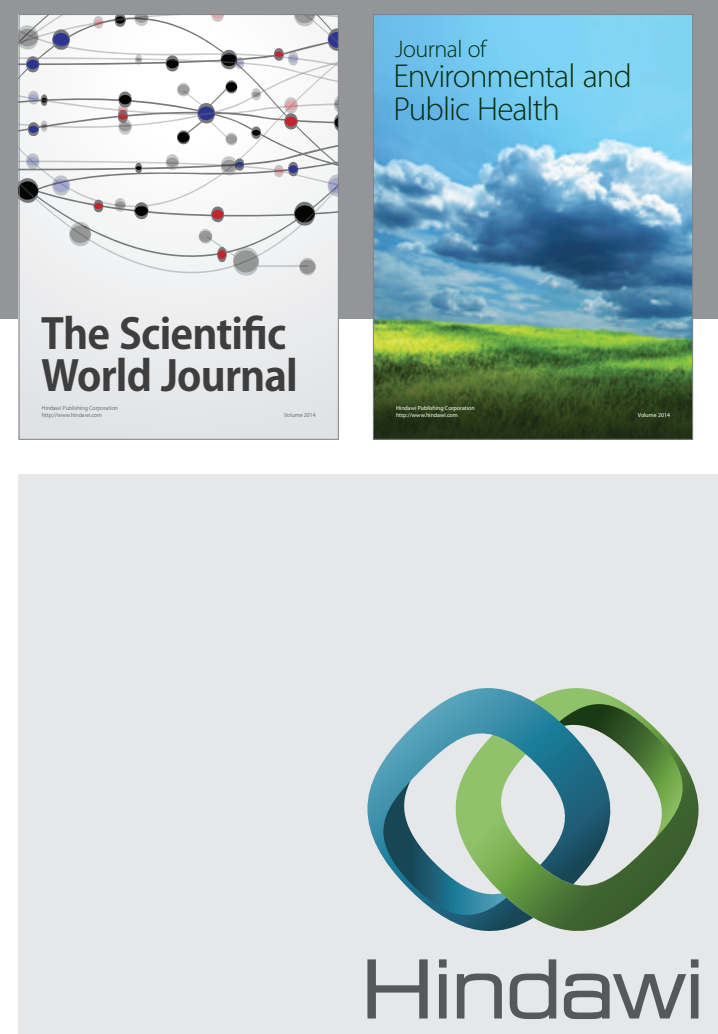

Submit your manuscripts at

http://www.hindawi.com
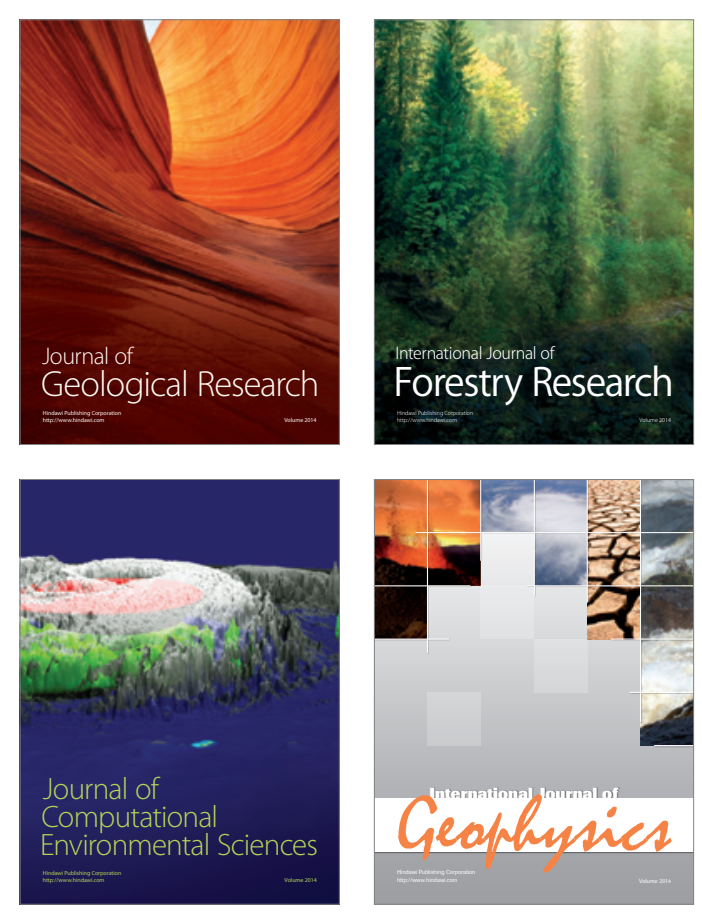
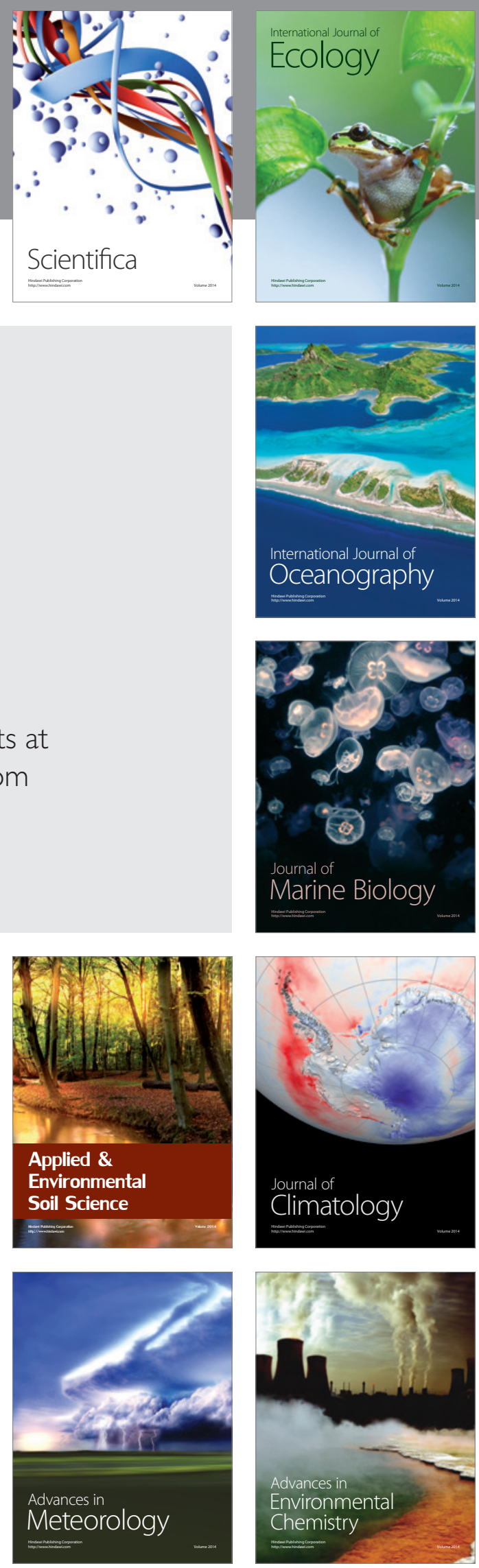